OPEN ACCESS

Edited by:

Marko Radic,

University of Tennessee College of Medicine, United States

Reviewed by:

Shun-Fen Tzeng

National Cheng Kung University,

Taiwan

Loredana Frasca,

National Institute of Health (ISS), Italy

*Correspondence:

Jan Voorberg

j.voorberg@sanquin.n

${ }^{+}$These authors have contributed equally to this work and share first authorship

Specialty section: This article was submitted to Autoimmune and Autoinflammatory Disorders,

a section of the journal

Frontiers in Immunology

Received: 11 August 2021

Accepted: 27 October 2021

Published: 11 November 2021

Citation:

Laghmouchi A, Graça NAG and Voorberg J (2021) Emerging Concepts

in Immune Thrombotic

Thrombocytopenic Purpura.

Front. Immunol. 12:757192. doi: 10.3389/fimmu.2021.757192

\section{Emerging Concepts in Immune Thrombotic Thrombocytopenic Purpura}

\author{
Aicha Laghmouchi ${ }^{\dagger}$, Nuno A. G. Graça ${ }^{\dagger}$ and Jan Voorberg * \\ Department of Molecular Hematology, Sanquin-Academic Medical Center Landsteiner Laboratory, Amsterdam, Netherlands
}

Immune thrombotic thrombocytopenic purpura (iTTP) is an autoimmune disorder of which the etiology is not fully understood. Autoantibodies targeting ADAMTS13 in iTTP patients have extensively been studied, the immunological mechanisms leading to the breach of tolerance remain to be uncovered. This review addresses the current knowledge on genetic factors associated with the development of iTTP and the interplay between the patient's immune system and environmental factors in the induction of autoimmunity against ADAMTS13. HLA-DRB1*11 has been identified as a risk factor for ITTP in the Caucasian population. Interestingly, HLA-DRB1 ${ }^{\star} 08: 03$ was recently identified as a risk factor in the Japanese population. Combined in vitro and in silico MHC class II peptide presentation approaches suggest that an ADAMTS13-derived peptide may bind to both HLA-DRB $1{ }^{*} 11$ and HLA-DRB1*08:03 through different anchor-residues. It is apparent that ITTP is associated with the presence of infectious microorganisms, viruses being the most widely associated with development of iTTP. Infections may potentially lead to loss of tolerance resulting in the shift from immune homeostasis to autoimmunity. In the model we propose in this review, infections disrupt the epithelial barriers in the gut or lung, promoting exposure of antigen presenting cells in the mucosa-associated lymphoid tissue to the microorganisms. This may result in breach of tolerance through the presentation of microorganism-derived peptides that are homologous to ADAMTS13 on risk alleles for iTTP.

Keywords: TTP (thrombotic thrombocytopenic purpura), DRB1*11, DRB1*08, infection-immunology, microbiota, tolerance, autoimmune disease

\section{INTRODUCTION}

Thrombotic thrombocytopenic purpura (TTP) is a rare and severe life-threatening autoimmune disorder which is mostly acquired by adult patients with an annual incidence of approximately 4 cases per million people (1). The patients suffer from systemic clumping of platelets in different organs due to the lack of activity of the metalloprotease ADAMTS13 (a disintegrin and metalloprotease with a thrombospondin type 1 motif, member 13) (1-3). The metalloprotease ADAMTS13 is responsible for the rapid processing of newly released von Willebrand factor (VWF) $(4,5)$. VWF is synthesized in endothelial cells and upon stimulation ultra-large VWF (UL-VWF) polymers are released in the systemic circulation. UL-VWF unfolds under high shear stress and 
stretches into string-like structures which enables ADAMTS13 to cleave the unfolded UL-VWF polymers thereby preventing spontaneous thrombi formation in the microvasculature $(6,7)$.

The diagnosis of immune TTP (iTTP) is not only based on the deficiency of ADAMTS13 activity but also on the presence of autoantibodies targeting ADAMTS13 (8-13). It was found that the majority of TTP patients develop autoantibodies that bind to the spacer domain of ADAMTS13, which is crucial for binding and subsequent processing of VWF (14-18). Autoantibodies targeting $\mathrm{N}$-terminal domains neutralize the proteolytic activity of ADAMTS13 while autoantibodies directed against other domains can cause accelerated clearance of ADAMTS13 from the circulation both resulting in the accumulation of UL-VWF polymers $(10,19$, 20). The retained UL-VWF strings on the surface of endothelial cells cause the formation of platelet clots within arteries and arterioles leading to microvascular thrombosis that subsequently gives rise to hemolytic anemia (disruption of red blood cells) and thrombocytopenia (systemic low level of platelets) that may cause skin hemorrhages, presenting as purple-colored spots on the skin (purpura) $(1,9,21)$.

The pathology of iTTP has been extensively studied for decades; the etiology of iTTP however, remains elusive. Here we will discuss our current knowledge on processes implicated with the development of autoimmune disorders (ADs) and their relevance for the development of autoimmunity against ADAMTS13, considering both genetic and environmental factors. In this review, we will also introduce a novel model describing the role of infections and microbiota in the onset and/ or relapses of iTTP.

\section{HLA ASSOCIATIONS IN ITTP}

The first suspicions concerning the involvement of genetic factors in TTP development rose from case reports describing the diagnosis of TTP in siblings $(22,23)$ and family members of different or same generation (mostly women) (24-27).
Involvement of HLA was first suggested by the development of TTP in two HLA-identical brothers in the early 1980's (25). The first large cohort study of HLA association in TTP was reported in the mid 1990's by Joseph and co-workers (28). This cohort study elegantly showed the absence of the HLA class II HLA$\mathrm{DRB} 1^{\star} 04$ allele (encoded by the DRB4 gene), indicating it to be a protective allele for TTP (28).

After the clear separation of TTP from hemolytic uremic syndrome (HUS) (29) and the distinction between congenital TTP and iTTP (30-32) the first risk alleles for iTTP were found almost simultaneously by two independent groups $(33,34)$. The HLA-DRB1 ${ }^{\star} 11: 01$ and HLA-DRB1 ${ }^{\star} 11: 04$ alleles were found in different European Caucasian populations as the most prominent risk factors among the HLA-class II alleles $(34,35)$. The different studies also confirmed the earlier discovered protective allele HLA-DR53 (allele DRB1*04) (33-35). In later studies similar observations were done and additional HLA associations were found, which have been summarized in Table 1. In a more recent study, it was found that the HLA risk alleles in the Japanese population were substantially different than for the European Caucasian populations. The main HLADRB1 allele identified as a risk factor for iTTP was found to be HLA-DRB1 ${ }^{\star} 08: 03$ (38). In contrast to HLA-DRB1* 11 , which is highly expressed in the European population, HLA-DRB1 ${ }^{\star} 08: 03$ is an allele unique to individuals with East Asian ancestry (Figure 1). Additionally, the absence of HLA-DR3, -DR4 and -DR5 haplogroups (DR3/4/5*blank) and the higher frequency of HLA-DQA $1^{\star} 01: 03$ and HLA-DQB $1^{\star} 06: 01$ were also associated with iTTP in the Japanese population. In contrast, the haplotype HLA-DRB1 ${ }^{\star}$ 15:01/DRB5 ${ }^{\star}$ 01:01 (known to be in strong linkage disequilibrium) was identified as a protective factor in the Japanese population (38).

HLA associations have been found for several other ADs, with some of the associated HLA alleles being risk factors for one disease, but protective for other diseases (e.g. HLA-DRB1 ${ }^{\star} 04$ is protective for iTTP in the general European Caucasian population, but a risk factor for giant cell arteritis (GCA) and

TABLE 1 | HLA associations reported for iTTP.

\begin{tabular}{|c|c|c|c|}
\hline HLA allele & Effect & Ethnicity & Author \\
\hline HLA-B18 & Predisposing & Caucasian & Coppo et al. (34) \\
\hline \multirow[t]{4}{*}{ DRB1*11 } & Predisposing & Caucasian & Scully et al. (33) \\
\hline & & Caucasian & Coppo et al. (34) \\
\hline & & Caucasian & John et al. (35) \\
\hline & & Children (mostly Caucasian) & Joly et al. (36) \\
\hline $\mathrm{DRB3}^{*}$ & Predisposing & Caucasian & Scully et al. (33) \\
\hline $\mathrm{DQB1}{ }^{\star} 02: 02$ & Predisposing & Caucasian & John et al. (35) \\
\hline DRB1*11-DQB1*03 & Predisposing & Caucasian & Sinkovits et al. (37) \\
\hline DRB1*15-DQB1*06 & Predisposing & Caucasian & Sinkovits et al. (37) \\
\hline DRB1*08:03 or DRB3/4/5(blank) & Predisposing & Japanese & Sakai et al. (38) \\
\hline \multicolumn{4}{|l|}{ or DQA $1{ }^{\star} 01: 03$ or DQB $1{ }^{\star} 06: 01$} \\
\hline \multirow[t]{3}{*}{$\mathrm{DRB} 1{ }^{\star} 04$} & Protective & Caucasian & Scully et al. (33) \\
\hline & & Caucasian & Coppo et al. (34) \\
\hline & & Children (mostly Caucasian) & Joly et al. (36) \\
\hline DRB1*07-DQB1*02 & Protective & Caucasians & Sinkovits et al. (37) \\
\hline DRB1*13-DQB1*06 & Protective & Caucasians & Sinkovits et al. (37) \\
\hline $\mathrm{DRB}^{\star}{ }^{15: 01}$ or DRB5${ }^{\star} 01: 01$ & Protective & Japanese & Sakai et al. (38) \\
\hline
\end{tabular}




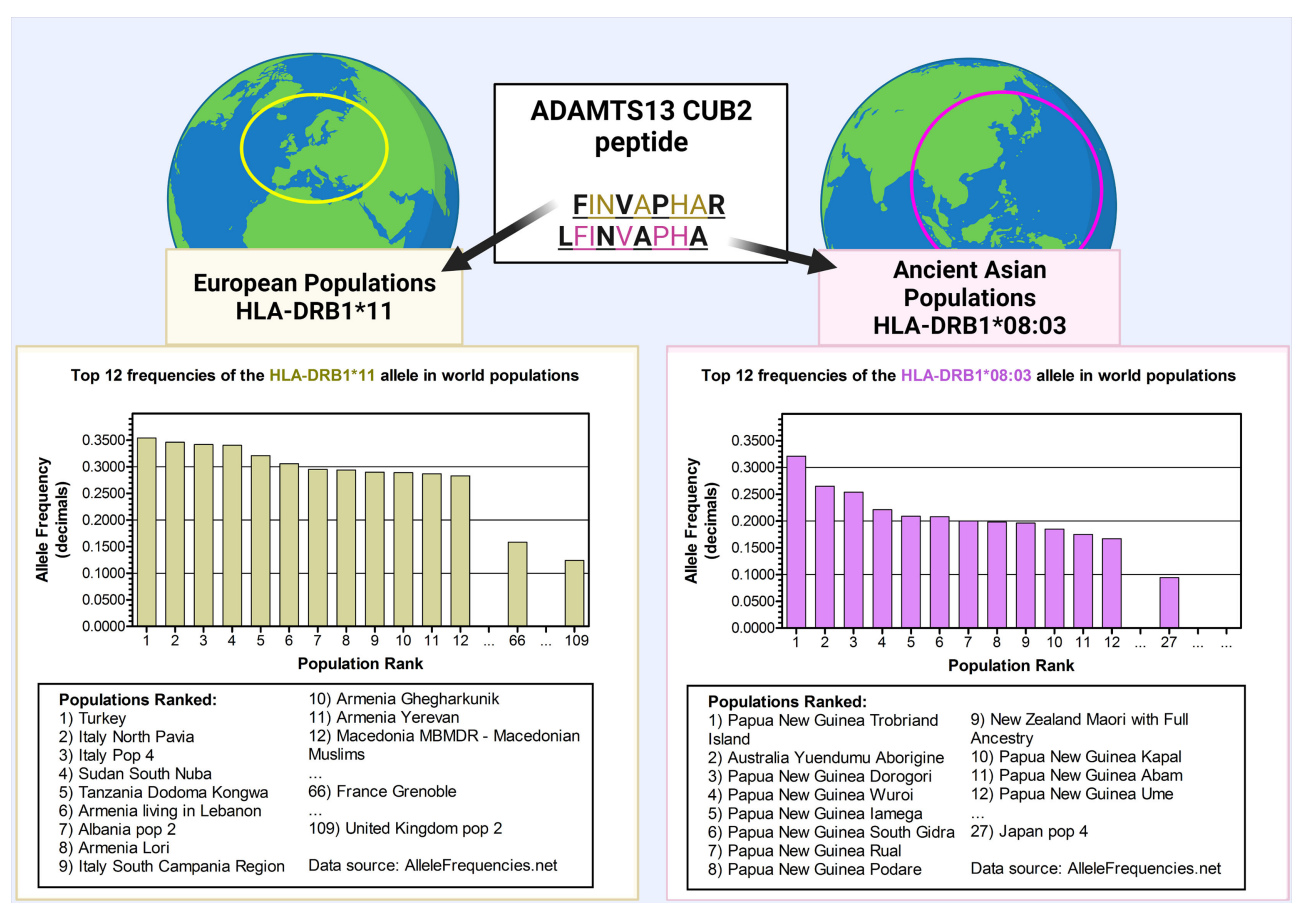

FIGURE 1 | The frequency of the predisposing alleles HLA-DRB1*11 and HLA-DRB1*08:03 in world populations. The HLA-DRB1*11 allele was found to be a predisposing factor in the European Caucasian populations. However, in Asian populations, the predisposing allele was found to be HLA-DRB1*08:03. These alleles bind the same ADAMTS13 peptide derived from the CUB2 domain, however it is predicted that in the context of HLA-DRB1*08:03, the HLA-DRB1*11:01-presented peptide $\underline{F}$ IN $\underline{V}$ P $H A \underline{R}$ is shifted with one amino acid, becoming LFINVAPHA. The top 12 world populations are shown with the highest frequencies for each allele. The first countries in the list are the countries in their continent (France and UK for Europe, and Japan for Asia) where the main association studies were performed. HLADRB1*11 allele was found to be not frequent in far-east Asian populations. The first far-east Asian population in the list is the Taiwan Hakka pop 2 (rank number 184 with frequency of 0.0960; - other middle-eastern populations in Armenia, Georgia, Iran, Iraq, and central Russia, as well as central-Asian populations in Pakistan and India, rank higher). Conversely, HLA-DRB1*08:03 was found to be not frequent in European populations, with the highest-ranking European population on the list being Portugal center (ranked as 106, with frequency 0.0200). Data source: allelefrequencies.net (access date: $20^{\text {th }}$ July 2021). Figure created with Biorender.com.

Rheumatoid Arthritis) (39). Not all people that possess risk alleles develop the corresponding $\mathrm{AD}$, which emphasizes the requirement of both genetic and environmental factors to lower the threshold for autoimmunity (37). To understand the role of HLA-DRB $1^{\star} 11$ and other HLA class II alleles in the pathogenesis of iTTP, it is crucial to perform studies that provide mechanistic insight into the role of HLA class II in the onset of disease.

\section{OTHER MOLECULAR CHECKPOINTS IN ITTP}

Other genetic factors like single-nucleotide polymorphisms (SNPs) were repeatedly implicated in several other autoimmune diseases, although the mechanism by which they influenced autoimmunity was not always clear (40). The analysis of functionally relevant SNPs in Toll-Like-Receptor-9 (TLR-9) revealed TLR-9 +2848G and TLR-9 +1174A genotypes to be more frequent in TTP patients (41). TLR-9 is an endosomal pattern recognition receptor that recognizes unmethylated-CpGcontaining DNA motifs from infectious microorganisms and directs Interferon-alpha production in humans and autoantibody development in mice (42). The gene protein tyrosine phosphatase nonreceptor type 22 (PTPN22) encodes lymphoid specific phosphatase (Lyp), a potent inhibitor of Tcell activation, and the SNP C1858T is a risk factor in certain autoimmune diseases (43). However, an analysis of the PTPN22 C1858T SNP did not show any difference between TTP patients and controls (37). More recently, two SNPs were found to be associated with the development of iTTP: rs6903608 (44) and rs9884090 (45). While there is lack of functional data, in silico analyses of these SNPs revealed that rs6903608 may increase expression of the risk HLA molecules for iTTP (44), while rs9884090 is associated with reduced expression of protein Oglycosyltransferase 1 (POGLUT1), implying that posttranslational modifications may shape the immune response towards ADAMTS13 (45).

Post translational modifications of antigens have long been recognized to play a role in certain autoimmune diseases (46). ADAMTS13 is an extensively glycosylated plasma protein, containing both $\mathrm{O}$-glycans and $\mathrm{N}$-glycans (47). It is known that alterations in glycosylation patterns may have impact on the immunogenicity of antigens (48). It is possible that in iTTP reduced $\mathrm{O}$-glycosylation of serines by POGLUT1 leads to altered 
antigen presentation in HLA risk alleles or altered T-cell receptor (TCR) recognition, however, functional data to confirm this hypothesis is still required. It is also noteworthy that ADAMTS13 as an antigen is more extensively modified by citrullination in the context of sepsis and in the elderly suffering from underlying comorbidities (49). This raises the possibility that citrullination of ADAMTS13 is another contributing factor for the loss of tolerance towards ADAMTS13, leading to iTTP. Citrullination was earlier described as a fundamental process in driving the autoimmune processes in rheumatoid arthritis and other inflammatory conditions (50), and was found to be capable of altering the specificity of TCRs towards T-cell epitopes, even though it did not impact HLA binding (51). Citrullination through peptidylarginine deiminase 4 (PAD4) drives the formation of neutrophil extracellular traps (NETs), which are normally triggered by infectious agents and contribute towards thrombosis by several mechanisms, including oxidation of ADAMTS13 methionines and possibly citrullination of ADAMTS13 through PAD4 (52). Biomarkers for NETosis were found to be elevated in iTTP patients (53). The conformational change of ADAMTS13 towards an open-state was also found as hallmark of iTTP and it is promoted through the binding of autoantibodies of patients (54, 55). Interestingly, non-inhibitory anti-ADAMTS13 autoantibodies also exist in healthy (56) and obese individuals (57). Like the pathogenic autoantibodies in iTTP patients, these should also promote the opening of ADAMTS13. The removal of C-terminal-domain N-glycans in ADAMTS13 may induce this open conformation state as well (58). The modifications and the confirmational change of ADAMTS13 may result in the availability of different and cryptic epitopes which may in turn help to contribute to the onset of iTTP.

\section{ADAMTS13-DERIVED PEPTIDES PRESENTATION}

The presentation of antigens in the context of HLA-class II molecules is required for the induction of adaptive immune responses. It is important to note that HLA-class II molecules usually bind $\sim 12-20$-mer peptides, while the core peptide inside the binding cleft normally consists of only 9-aminoacids, of which a few serve as anchor residues creating specific peptide binding motifs (usually involving aminoacid positions P1, P4, P6 and P9). HLA-class II peptides are not restricted by a closed peptide binding cleft structure of the HLA molecule as is the case for HLA-class I molecules (59). HLA-class II molecules display much more flexibility, allowing for differences in positioning of peptides within the peptide binding cleft and differences in the peptide flanking residues. Therefore, HLA-II molecules are known to have a certain degree of promiscuity - that is, one HLA-II molecule binds many different peptides. On the other hand, peptides have also been found to show a degree of promiscuity towards HLA-II molecules $(60,61)$. Consequently, some HLA-class II restricted T-cell receptors are capable of recognizing more than one HLA class II-peptide complex with different affinities $(59,60,62)$. The ADAMTS13-peptidomes for HLA-DR and HLA-DQ (Figure 2) were dissected and it was revealed that the majority of eluents contained peptides derived from the ADAMTS13 CUB2 domain with the core sequence 'FINVAPHAR' (HLA-DRB1 ${ }^{\star} 11$ ) or a different CUB2 peptide with the core sequence 'LIRDTHSLR'. The latter was eluted from HLA-DRB1 ${ }^{\star} 03$, an allele not formally associated with TTP (63). Peptides containing each of these core sequences were later shown to activate CD4 T-cells from TTP patients expressing the respective HLA-DRB1 alleles (65).

Elution experiments have demonstrated that promiscuity is a prominent feature of ADAMTS13 derived peptides. A notorious example is the 'FIN $\underline{V A} \underline{P} H A \underline{R}$ ' core peptide from the ADAMTS13 CUB2 domain which was shown to bind to different HLA-DR alleles (63). Interestingly, the core peptide 'FINVAPHAR' which was eluted from HLA-DRB1*11:01, was also predicted to be the highest affinity peptide for the risk factor HLA-DRB $1^{\star} 08: 03$ in the Japanese population, although the core sequence showed a shift of one amino acid, becoming 'LFINV $\underline{A} P H \underline{A}^{\prime}$ (Figure 1). This strongly suggests that HLAbinding peptides containing this core structure will likely be capable of binding to both HLA-DRB1*11:01 as well as HLA$\mathrm{DRB}^{\star}{ }^{\star 08: 03}$ (38). Promiscuity was also shown for other ADAMTS13 peptides (e.g. the ADAMTS13-1239-1253 peptide, or GDMLLLWGRLTWRKM - a CUB1 peptide - and the core sequence 'LLRDPSLGA' - a metalloprotease peptide) (64). The ADAMTS13 peptidome for HLA-DQ was also assessed, and the same type of promiscuity was observed among these alleles. Peptides with the core sequence 'QADCAVAIG' (CUB1 domain) were eluted from two different haplotypes (64). Peptide promiscuity is also possible between different HLA class II molecules (i.e. the same peptide binding both HLA-DR and HLA-DQ) (66). The 'QADCAVAIG' core peptide found in the HLA-DQ elution study was also found for HLA-DR although the predicted core was slightly different ('CAV $\underline{A} I \underline{G} R \underline{L}$ '). The same applied to the peptides with the core 'LLRDPSLGA' eluted for HLA-DR, which were obtained also from HLA-DQ elution although with a slightly different predicted core sequence 'LRDPSLGAQ' (64). Overall, in the different elution experiments more peptides were eluted from HLA-DR alleles than HLA-DQ, which is probably influenced by the expression of the HLA molecules and the lower binding affinities of ADAMTS13 peptides in HLA-DQ (64) as was also shown for coagulation Factor VIII (66).

\section{THE ROLE OF AUTOREACTIVE CD4 T CELLS IN ITTP}

The prominent HLA-class II association of iTTP combined with the presentation of ADAMTS13-derived peptides (including immunogenic peptides) on risk alleles for iTTP strongly supports a pivotal role for CD4 T cells in the immunopathogenesis of iTTP. Subclass and clonal analyses of anti-ADAMTS13 antibodies from iTTP patients provided evidence for isotype switching and affinity maturation $(9,10,20,67-69)$. These immunological processes 


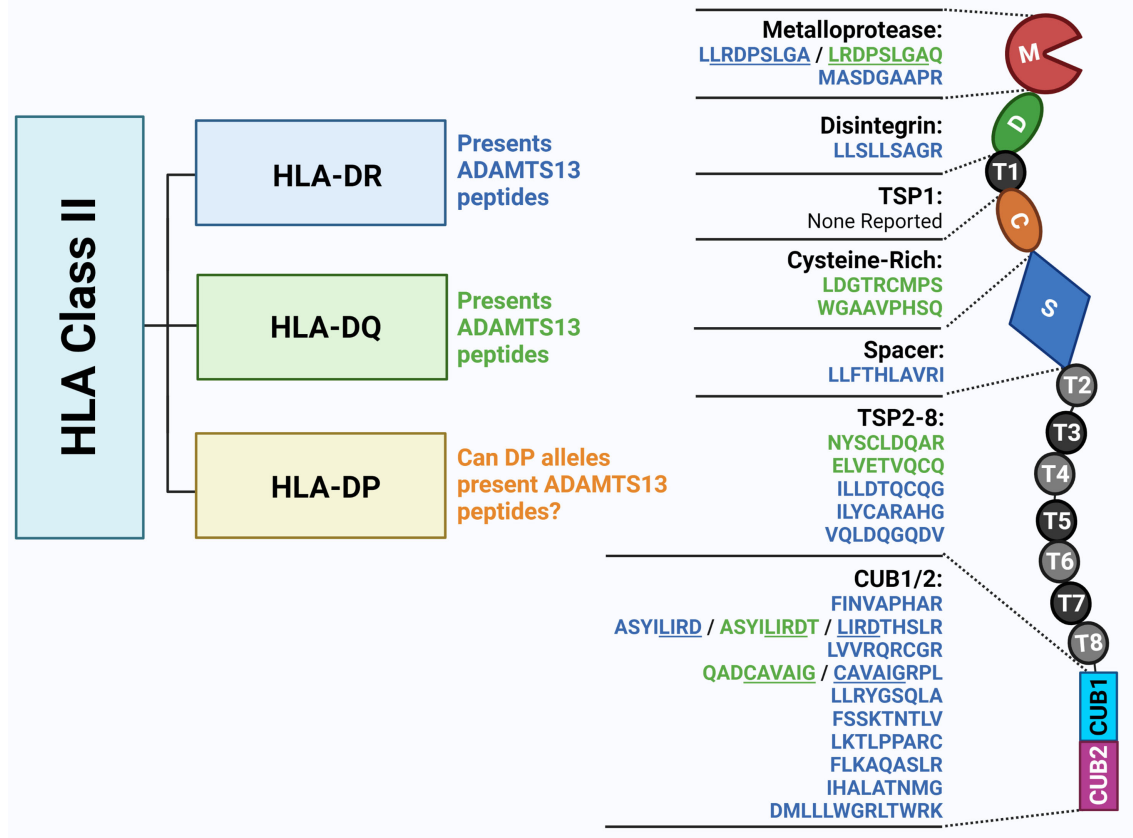

FIGURE 2 | The ADAMTS13 peptidome presented by HLA Class II molecules. Previous studies unravelled ADAMTS13 peptides presented by HLA-DR and HLADQ molecules by peptide elution. The monocytes from HLA-DR and HLA-DQ-genotyped healthy donors were isolated and differentiated into dendritic cells (DC). DC were loaded with ADAMTS13, and upon lysis, HLA-II/peptide complexes were isolated by immunoprecipitation. Following elution ADAMTS13-peptides were identified through mass spectrometry. The 9-mer core sequences of the eluted peptide shown in this figure were identified through NetMHCllpan 3.1 software (in blue for HLA-DR alleles and in green for HLA-DQ alleles) $(63,64)$. Figure created with Biorender.com.

further corroborate the role of CD4 $\mathrm{T}$ cells in the autoimmune responses against ADAMTS13. CD4 (helper) T cells are part of the adaptive immunity and are required for immune responses against pathogens or tumors. The T-cell receptors (TCR) of CD4 T cells bind to peptides in the context of HLA-class II (HLA-DR, HLA-DQ or HLA-DP) molecules on antigen-presenting cells (APC) $(70,71)$. The activation of CD4 T cells does not only depend on the binding of their TCR with peptide-HLA complexes but also on the binding of CD4 T cells with co-stimulatory (CD80 and/or CD86) and adhesion molecules (CD54) expressed by professional APC (72, 73). The naïve CD4 $\mathrm{T}$ cells differentiate upon activation by professional APC into various effector CD4 T-cell subsets, such as Th1 (74), Th2 (75), Th17 (76), T follicular (Tfh) (77) or regulatory T (Treg) cells (78). The CD4 T-cell fate is influenced by the cytokines produced by APC after which the differentiated T-cell subsets migrate to their target location to exert their function (73).

In ADs, auto-reactive CD4 $\mathrm{T}$ cells are used to induce the generation of autoantibodies by $\mathrm{B}$ cells. During $\mathrm{T}$-cell development in the thymus, the $\mathrm{T}$ cells binding strongly to selfpeptides presented in self-HLA are eliminated from the T-cell repertoire. However, a large part of the autoreactive $\mathrm{T}$ cells with a low or intermediate affinity escape negative selection and become part of the T-cell repertoire (71, 79-81). Autoreactive T cells involved in the development of iTTP and other ADs are required to possess a proper functional avidity to become activated by selfantigens. The avidity of T cells is determined by the TCR affinity to the peptide in the context of an HLA molecule. TCRs have been shown to bind differently to HLA-peptide complexes depending if the peptide is derived from a foreign antigen or from a self-protein. For foreign T-cell epitopes, the binding takes place with the TCR in a diagonal position relative to the HLA-peptide complex, with the CDR3 variable domains centered in the P5 position of the embedded peptide. In the case of self-peptides the docking may be altered, and examples where it may be shifted towards the $\mathrm{N}$ terminal region of the peptide, or tilted in such a way that only the variable beta chain of CDR3 maintains contact with the HLApeptide complex have been found (82). Besides the TCR binding, also the binding with stimulatory and adhesion molecules and the internal signaling transduction are important in the activation of CD4 T cells (83-85). In the context of iTTP, autoreactive CD4 T cells are hypothesized to be activated by APC that take up ADAMTS13 (using, for example, the macrophage mannose receptor (MR) or CD163) (86, 87). Upon endocytosis, ADAMTS13-derived peptides are loaded onto the HLA-class II molecules (63) and are recognized by the autoreactive CD4 T cells. Upon peptide recognition and co-stimulation, the CD4 T cells get activated and differentiate into effector CD4 T cells that secrete cytokines which subsequently stimulate antigen-specific B cells to differentiate into autoantibodies-producing plasma cells $(20,88)$.

The role of CD4 T cells in the development of iTTP is a clear given, as CD4 help is required in the production and affinity maturation of ADAMTS13-directed antibodies. However, the 
exact trigger for the activation of autoreactive CD4 $\mathrm{T}$ cells remains unclear. Like most ADs (86), iTTP is generally considered to be very rare (1), however the association between infection and the development of iTTP is evident. The high prevalence of infections at time of diagnosis (41\%) (41) suggest that these pathogens are at least one of the triggers involved in the loss of tolerance towards ADAMTS13.

\section{MOLECULAR MIMICRY AND AUTOIMMUNE DISORDERS}

The etiology of ADs involves different factors including the genetic predisposition of the patient, but also the intricate interplay between the patient's immune system and environmental factors $(89,90)$. The development of autoimmunity has often been associated with the occurrence of an infection which can be explained by the mechanism of 'molecular mimicry', the similarities between pathogen- and self-peptides resulting in the activation of autoreactive T or B cells in genetically susceptible individuals (8992). Molecular mimicry is generally considered when four major criteria are met: 1) similarities between pathogen-derived antigens and self-antigens; 2) antibodies or T cells are detected that crossreact with both epitopes; 3) an epidemiological correlation/ association between infection and onset of autoimmunity is present; 4) the development of the autoimmune disease is reproduced in an animal model by exposing the animal to the pathogen-derived cross-reactive antigen (89). In the past decades a variety of ADs were assumed to be caused by molecular mimicry as the antibodies or T cells demonstrated specificities directed against epitopes shared by pathogens and self-antigens. Only one autoimmune disease was found to fulfill all four listed criteria for molecular mimicry and that was Guillain-Barré syndrome resulting from C. jejuni infection (93). However, in many other ADs (type I diabetes, rheumatoid arthritis, systemic lupus erythematosus, Sjögren's syndrome, systemic sclerosis, autoimmune thyroid disease, autoimmune liver diseases, autoimmune hepatitis, primary biliary cholangitis), and also in the context of vaccines, molecular mimicry was suggested to be the underlying mechanism but was not formally demonstrated due to lack of fulfillment of all the four criteria outlined above (89).

\section{Infections Associated With iTTP}

The development of iTTP has been associated with a variety of viral or bacterial infections as infections were found to be highly prevalent at time of diagnosis (41). We performed a literature search spanning the last 20 years which shows that several viruses, bacteria and other pathogens have been associated with the diagnosis of iTTP (Figure 3). The top three pathogens with a significant number of reports are: HIV, Hepatitis C, and Influenza (A) viruses, respectively. In the case of Influenza infection, it was previously observed that the heavy chain gene segment VH1-69 was preferred in antibodies targeting a highly conserved region in the hemagglutinin ectodomain of the virus (94). The same gene segment VH1-69 was also preferably used in antibodies directed towards ADAMTS13 (95-97). Future studies are required to address the possibility that the ADAMTS13 antibodies are in fact cross-reactive VH1-69 encoded antibodies targeting viral antigens (20). In Table 2 an overview of all the microorganisms associated with the occurrence of iTTP is given. The pathogens' target organs or target cells are listed, as well as one exemplary reference for each microorganism reporting a clear association between iTTP (defined as ADAMTS13 activity $<10 \%$ and presence of anti-ADAMTS 13 antibodies) and the infection. Associations between infection and iTTP must be made with caution. One must differentiate between secondary iTTP due to infection (that is, anti-ADAMTS13 autoantibodies developed due to the presence of the infectious microorganism) from secondary TTP caused either by the systemic inflammation and/or endothelial damage which commonly accompanies infections $(13,52,115)$, or secondary TTP caused by drugs, or liver cirrhosis, or excessive alcohol intake $(116,117)$, as well as from other coagulation disorders well known to occur with infectious diseases $(118,119)$. The presence of autoantibodies together with ADAMTS13 activity $<10 \%$ is the defining factor for this differentiation.

Furthermore, congenital TTP can be discovered because of infections and is frequently exacerbated as relapses or acute thromboembolic events due to infections (120, 121). The mechanisms involved in coagulation and thrombosis in infections are complex, transient, and ubiquitous to inflammatory cytokines $(118,119,122)$. These also concur for reduced ADAMTS13 activity by tilting the balance in the ADAMTS13-VWF axis towards VWF in 3 ways: a) increase in VWF antigen levels (increased production and release of UL-VWF polymers from the endothelium); b) direct reduction of ADAMTS13 activity (123); and c) reduction of ADAMTS13 antigen (reduced ADAMTS13 synthesis in the liver and endothelium) (124). This is well documented in the case of COVID19 patients, where a "cytokine storm" is present and allows for such imbalance, with evidence for higher VWF antigen levels and lower ADAMTS13 activity in several cohorts (125). It is also evident through the accumulation of UL-VWF and lower ADAMTS13 activity in the plasma of COVID19 patients, which can be rescued by addition of recombinant human ADAMTS13 in vitro (126). Therefore, iTTP must formally be demonstrated in any association, and even if iTTP is proven, it is not always possible to attribute a direct causal relationship to one specific pathogen. For example, in an immunosuppressed patient multiple infectious agents may be present at the same time (notorious examples include HIV together with HCV (127), or opportunistic infections) and in other cases multiple conditions can be associated, such as other ADs or malignancies (128).

\section{Vaccines Associated With iTTP}

Some reports described an association between vaccine administration and development of iTTP (examples listed in Table 3) (139). Influenza is commonly associated to TTP, and cases where ADAMTS13 autoantibodies were developed following influenza infection have been described (99). Globally, during the last 50 years only a few cases of TTP have been documented for influenza vaccines (Table 3) (139), even though 3100 million seasonal influenza vaccine doses have been administered in the United States of America alone since 1980 (140). A similar remark can be made of COVID vaccines, where, 


\section{Microorganisms associated with immune TTP (2001-2021)}

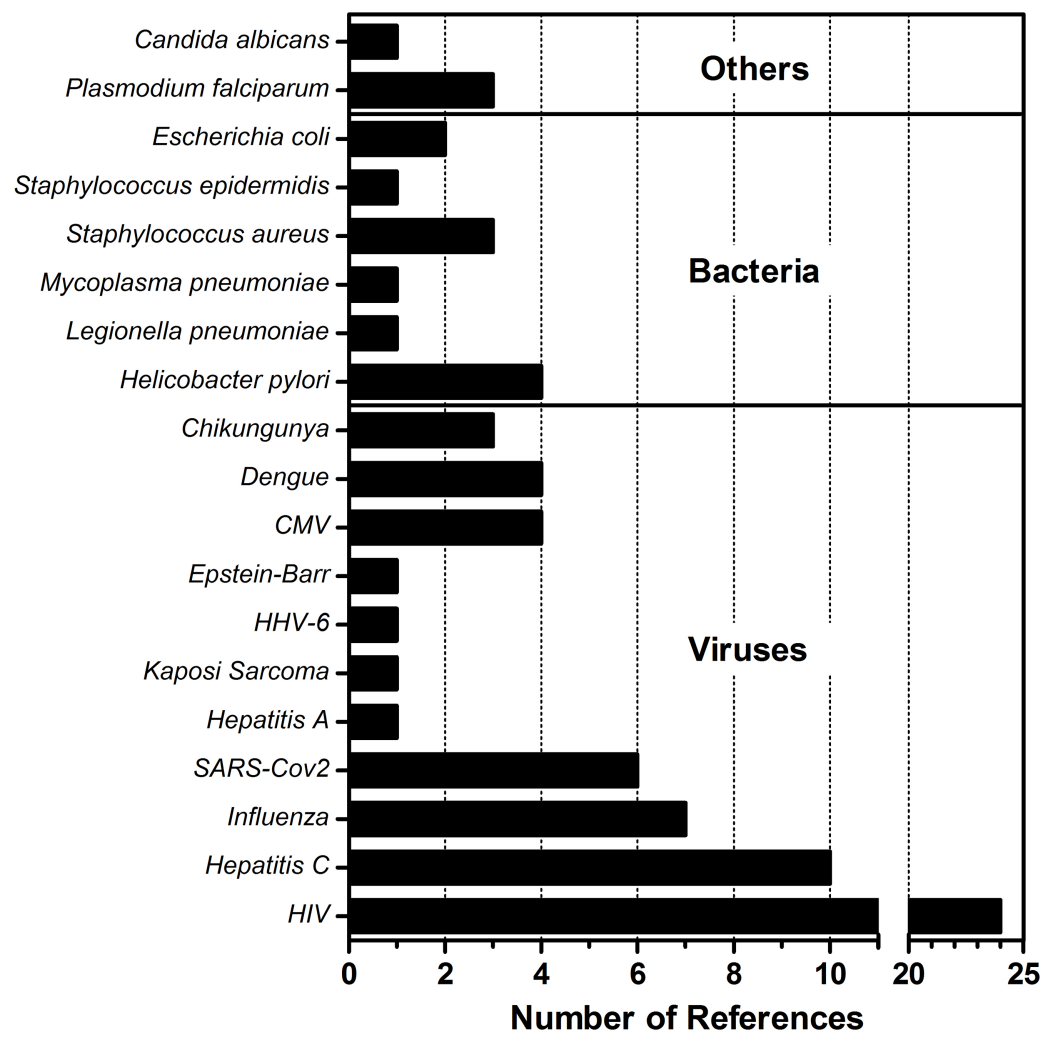

FIGURE 3 | Microorganisms associated with immune TTP. The number of obtained references for different pathogens associated with the development of iTP are presented in this bar-chart. The literature search was performed using the PubMed database, employing the search terms 'thrombotic thrombocytopenic purpura' AND 'infection' NOT 'hereditary' NOT 'congenital' NOT 'immune thrombocytopenic purpura' AND 'Case Report'. References since 2001 (the year when ADAMTS13 was formally discovered and its structure annotated) were swept through to find infectious microorganisms that could be identified as a trigger for immune TTP in case reports under specific criteria: 1) the diagnosis of acquired TTP was done shortly after the infection was identified, or the infection was clearly associated as trigger of a relapse, 2) ADAMTS13 activity was preferably measured as <10\%, 3) anti-ADAMTS13 autoantibodies were detected, confirming the diagnosis of immune TTP. The search was performed on the $28^{\text {th }}$ April 2021.

at the time of writing, only 2 cases of relapsing iTTP $(134,135)$ and 8 de novo iTTP cases $(136-138,141)$ were identified, among many millions of doses administered currently in the world. In this context, it is important not to confuse iTTP with vaccineinduced thrombotic thrombocytopenia (VITT), which has different mechanisms compared to iTTP (142, 143). Arguments for molecular mimicry in development of autoimmunity can still be made in the context of vaccines (144).

\section{Molecular Mimicry in iTTP}

In the context of iTTP the mechanism of molecular mimicry (Figure 4) is hypothesized to occur when the microorganism is recognized by pattern recognition receptors (PRR) on APC followed by the uptake via the process of endocytosis. After antigen processing the microorganism-derived peptides (peptides 1 in table) are loaded onto the HLA-class II molecule (the risk allele HLA-DRB $1^{\star} 11$ or HLA-DRB $1^{\star} 08: 01$, respectively) and presented to the TCR of an autoreactive CD4 T cell. The CD4 T cell crossreacts with ADAMTS13-derived peptides (peptides 2 in table) presented in the HLA-II molecule (HLA-DRB1*11 or HLA$\mathrm{DRB} 1^{\star} 08: 01$, respectively), these peptides show similarities with the microorganism-derived peptides for certain aminoacid positions. The co-stimulatory and adhesion molecules (CD80/ CD86 and CD54, respectively) on the APC are required for the activation of the autoreactive CD4 T cells. The ADAMTS13-derived peptides are obtained by the uptake of ADAMTS13 using the mannose receptor on APC. The cytokines produced by the APC are required for the differentiation of the naïve CD4 $\mathrm{T}$ cell into an effector CD4 T-cell population (Figure 4).

The observed associations with either infections or vaccines in the development of iTTP have not been substantiated as of yet by a direct link to a specific pathogen antigen resembling ADAMTS13. The only exception is with Influenza, where a computational analysis was undertaken to assess if there are any sequences of the Influenza proteome that may resemble any part of the ADAMTS13 sequence and serve as cross-reactive T-cell epitopes (145). However, this analysis was done based on similarities at a 5-mer peptide level, less than the 9-mer core peptides necessary to bind the HLA 
TABLE 2 | Pathogens associated with iTTP.

\begin{tabular}{|c|c|c|c|}
\hline Pathogens & & Target Organs/Cells & Reference \\
\hline \multirow[t]{10}{*}{ Viruses } & Human Immune-deficiency virus (HIV) & T-lymphocytes & (98) \\
\hline & Influenza A & Respiratory Tract & (99) \\
\hline & SARS-CoV2 & Respiratory Tract & $(100)$ \\
\hline & Hepatitis $\mathrm{C}$ and $\mathrm{A}$ viruses & Liver & $(101,102)$ \\
\hline & $\begin{array}{l}\text { Human gammaherpesvirus-8 } \\
\text { (HHV-8, Kaposi Sarcoma) }\end{array}$ & Vascular Endothelium & (103) \\
\hline & $\begin{array}{l}\text { Human Herpes-virus type } 6 \\
(\mathrm{HHV}-6)\end{array}$ & $\begin{array}{l}\text { T-lymphocytes, neurons, } \\
\text { salivary glands }\end{array}$ & $(104)$ \\
\hline & $\begin{array}{l}\text { Human gamma herpesvirus } 4 \\
\text { (HHV-4, Epstein-Barr Virus) }\end{array}$ & B-lymphocytes, epithelial mucosa & $(105)$ \\
\hline & Cytomegalovirus & Epithelial mucosa & $(106)$ \\
\hline & Dengue & Langerhans cells in skin; vascular endothelium & $(107)$ \\
\hline & Chikungunya virus & Fibroblasts in skin, myocytes & $(108)$ \\
\hline \multirow[t]{7}{*}{ Bacteria } & Helicobacter pylori & Stomach & (109) \\
\hline & Legionella pneumoniae & Respiratory Tract & (110) \\
\hline & Mycoplasma pneumoniae & Respiratory Tract & $(111)$ \\
\hline & Atypical Community Acquired Pneumonia (undefined microorganism) & Respiratory Tract & $(112)$ \\
\hline & Staphylococcus spp. & Urinary tract & (113) \\
\hline & Escherichia coli & Urinary Tract & (113) \\
\hline & Staphylococcus aureus & Systemic (Septicaemia) & $(113)$ \\
\hline \multirow[t]{2}{*}{ Others } & Candida albicans & Systemic & $(102)$ \\
\hline & $\begin{array}{l}\text { Plasmodium falciparum } \\
\text { (Malaria/Blackwater Fever) }\end{array}$ & Liver; red blood cells & $(114)$ \\
\hline
\end{tabular}

molecules, and should therefore be refined. No cross-reactive B-cell epitopes have been formally identified yet. Overall, the evidence is suggestive that infections are linked to the onset and/or recurrence of iTTP. However, the mechanism by which these infections promote the development of iTTP is not yet clear.

\section{THE BREAKDOWN OF TOLERANCE IN IMMUNE TTP}

\section{Microbiota and the Development of Autoimmune Disease}

The development of iTTP has been associated with both intrinsic as well as extrinsic factors. Genetic and other molecular checkpoints were found and suggested as predisposing intrinsic factors in patients. The association with different types of infection and the rarity of disease manifestation under the described conditions suggest that not only the genetic factors and the specific infection are involved, but that other environmental cues are at play. These should affect larger parts of the population and would tilt the balance from immune homeostasis to autoimmunity only in individuals with these predisposing factors, and only within

TABLE 3 | Vaccines associated with iTTP.

\begin{tabular}{lc}
\hline Vaccines & References \\
\hline Influenza Seasonal Vaccine & $(129,130)$ \\
Pneumococcal Vaccine & $(131)$ \\
Influenza, Pneumococcal, Triple Diphtheria-Tetanus-Poliomyelitis & $(132)$ \\
Vaccines & \\
Rabies Vaccine & $(133)$ \\
COVID Vaccine & $(134-138)$
\end{tabular}

specific situations that allow for the correct spatio-temporal alignment of the cross-reactive $\mathrm{T}$ and $\mathrm{B}$ cells.

One such environmental cue are the microbiota. Microbiota are known to be dependent on geographic regions, ethnicities and subsistence, with drastic variations among the different areas of the globe (146). The HLA system is known to interact with the gut microbiome, shaping its composition (147) and, simultaneously, the microbiome itself exerts systemic effects on the immune system, which has implications for immune homeostasis (148). Microbiota and dysbiosis have been the subject of many studies concerning the development of ADs, prominently in Type I diabetes mellitus (T1D). Initially, the increased incidence of T1D throughout time in genetically stable populations pointed towards effects coming from rapid improvements in public health and treatment of childhood illnesses that may have impacted the gut microbiota. Today there is a plethora of longitudinal prospective studies in humans and animal models supporting these hypotheses, including associations between HLA risk/protective alleles and microbiota composition and development of T1D (149-151).

The composition of microbiota was also found to influence the susceptibility to infections and the immune responses against infections (152). It has been suggested that in some ADs, the infections could cause the disruption of epithelial cell layers in organs (153). During immune homeostasis, the epithelial cell layer functions as a physical barrier to prevent the interaction of microbiota and antigen presenting cells in the mucosal associated lymphoid tissues to avoid undesirable activation of the host immune system. However, upon epithelial damage the microbiota can translocate beyond barrier surfaces like the gut, skin, lung and other mucosal surfaces and subsequently interact with immune cells (153). Microbiota-derived antigens - like pathogen-derived antigens - can share similarities with selfantigens which then may activate autoreactive T and B cells. 


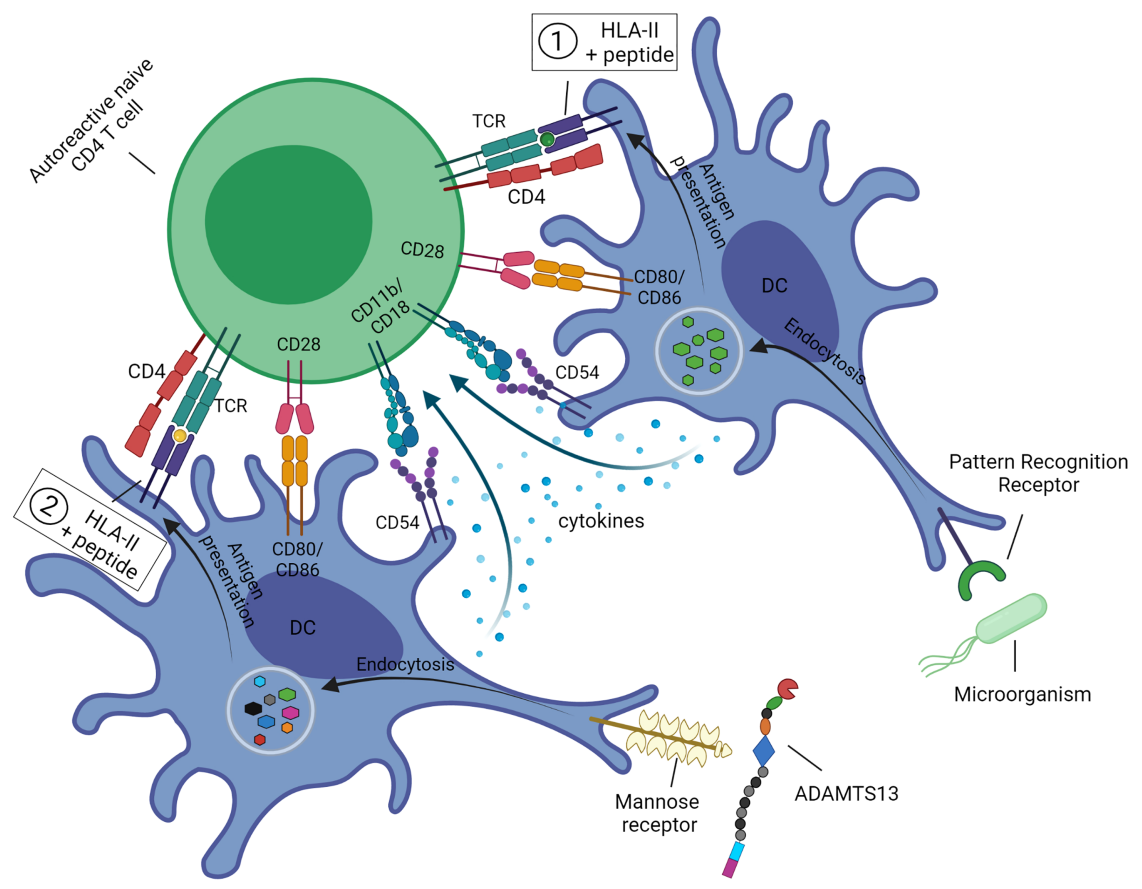

\begin{tabular}{|c|c|c|c|}
\hline & Origin & $\begin{array}{c}\text { HLA-DRB1*11 } \\
\text { + peptide }\end{array}$ & $\begin{array}{c}\text { HLA-DRB } 1 * 08 \\
\text { + peptide }\end{array}$ \\
\hline 1 & Microorganism & 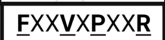 & $\underline{L} X X \underline{N} \times \underline{A} X X \underline{A}$ \\
\hline 2 & ADAMTS13 & FINVAPHAR & LFINVAPHA \\
\hline
\end{tabular}

FIGURE 4 | Potential role of molecular mimicry in iTTP. The microorganism is recognized by pattern recognition receptors (PRR) on APC (in this figure, dendritic cells, DC) followed by the uptake via the process of endocytosis. After antigen processing the microorganism-derived peptides (peptides 1 in table) are loaded onto the HLA-class II molecule (the risk allele HLA-DRB1*11 or HLA-DRB1*08:01, respectively) and presented to the TCR of an autoreactive CD4 T cell. The CD4 T cell cross-reacts with ADAMTS13-derived peptides (peptides 2 in table) presented in the HLA-II molecule (HLA-DRB1*11 or HLA-DRB1*08:01, respectively). The ADAMTS13-derived peptides show similarities with the microorganism-derived peptides for certain aminoacid positions (for example the anchor residues as indicated by the bold and underlined letters). The co-stimulatory and adhesion molecules (CD80/CD86 and CD54, respectively) on the APC are required for the activation of the autoreactive CD4 T cells. The ADAMTS13-derived peptides are obtained by the uptake of ADAMTS13 using the mannose receptor on APC. The cytokines produced by the APC are required for the differentiation of the naïve CD4 T cell into an effector CD4 T-cell population. Figure created with Biorender.com.

\section{A Role for Microbiota in Development of iTTP?}

In the context of iTTP, there are no studies performed on the microbiota of patients to this date, and there are also no animal models that mimic the immune response against ADAMTS13 (154). However, additional ADs are frequently observed in iTTP patients, one of the most prevalent being Systemic Lupus Erythematosus (SLE). There are already extensive studies showing a role for microbiota in SLE development (155). This body of knowledge should be translational towards iTTP. The combination of infections and extensive exposure of the immune system to microbiota facilitates the "breach" in tolerance for self (see Box 1), and this may be the case for iTTP.

The current knowledge allows us to propose a model for the role of infections and microbiota in the development of autoimmunity against ADAMTS13 in iTTP patients (Figure 5). Infections are responsible for disrupting the epithelial cell layer, which results in the immune system being exposed to microbiota in addition to infectious pathogens (step 1). The APC (DC or macrophages) can acquire antigens from microorganisms as the epithelial cell layer is breached (step 2). The APC phagocytize and process the antigens, and present them to naive CD4 T cells (step 3). The autoreactive naive $\mathrm{CD} 4 \mathrm{~T}$ cells that escaped the selection process cross-react against ADAMTS13-derived antigens presented after uptake and processing of ADAMTS13 protein (step 4). The activated CD4 T cells differentiate into effector $\mathrm{CD} 4 \mathrm{~T}$ cells, which are involved in the induction of antibody responses (step 5). The autoreactive CD4 T cells interact with autoreactive B cells (step 6) to induce differentiation of the B cells into autoantibodies-producing plasma cells (step 7) (Figure 5).

\section{CONCLUDING REMARKS AND FUTURE PERSPECTIVES}

The aim of this review was to unravel the etiology of iTTP by addressing both genetic and environmental factors involved in 
BOX 1 | Self and non-self.

The breach of self-tolerance towards ADAMTS13 is - as with any autoimmune process - dictated by factors of 'self' and 'non-self'. Among the 'self' factors we have intrinsic factors like the possibility of HLA class I and class II peptides' loading, which is directly dependent on the HLA haplotypes possessed by individuals, and dependent on possible variations in other 'self' antigens that may impact T-cell epitopes affinities to their respective HLA molecules (59), and other genetic factors that modulate the immune response (e.g. single nucleotide polymorphisms that modulate expression of proteins either directly involved in the immune synapse, or of other proteins involved in immune responses) (156-158), and - in a way, as an intrinsic factor - the microbiome, which is specific of each individual and region (146). On the other hand, the microbiome can also be considered as an extrinsic factor for 'self' (or an intrinsic factor for 'non-self'), if we consider the human body as a superorganism that is, a single entity composed of multiple organisms, in this case 1) the human body itself and 2) the total set of microorganisms that colonize the gut, vital to the shaping of immune responses that take place in the human body, and towards which the human immune system becomes inherently tolerant since birth (159). On the 'non-self' side, the most important extrinsic factor is the proteome of the total number of microorganisms the individual encounters throughout its life-span (regardless of their natural ability to cause diseases). A certain degree of overlap is inevitable between these types of factors due to the co-evolution of the human immune system shaped by the contact with microorganisms (160). On the edge of both types of 'self'-'non-self' factors stands the variable of time. Time influences the immune processes in two ways: 1) through the cumulative experience of host-microorganism interactions, allowing to build a B- and T-cell repertoire; 2) through a direct impact of aging on the individual's characteristics at the levels of a) antigen repertoire and b) immune senescence (161-163). All these factors concur in this dynamic homeostatic process that dictates what is 'self', what is 'non-self', and when each of these entities are perceived as such by the human immune system ('liquid-self' theory) (161).

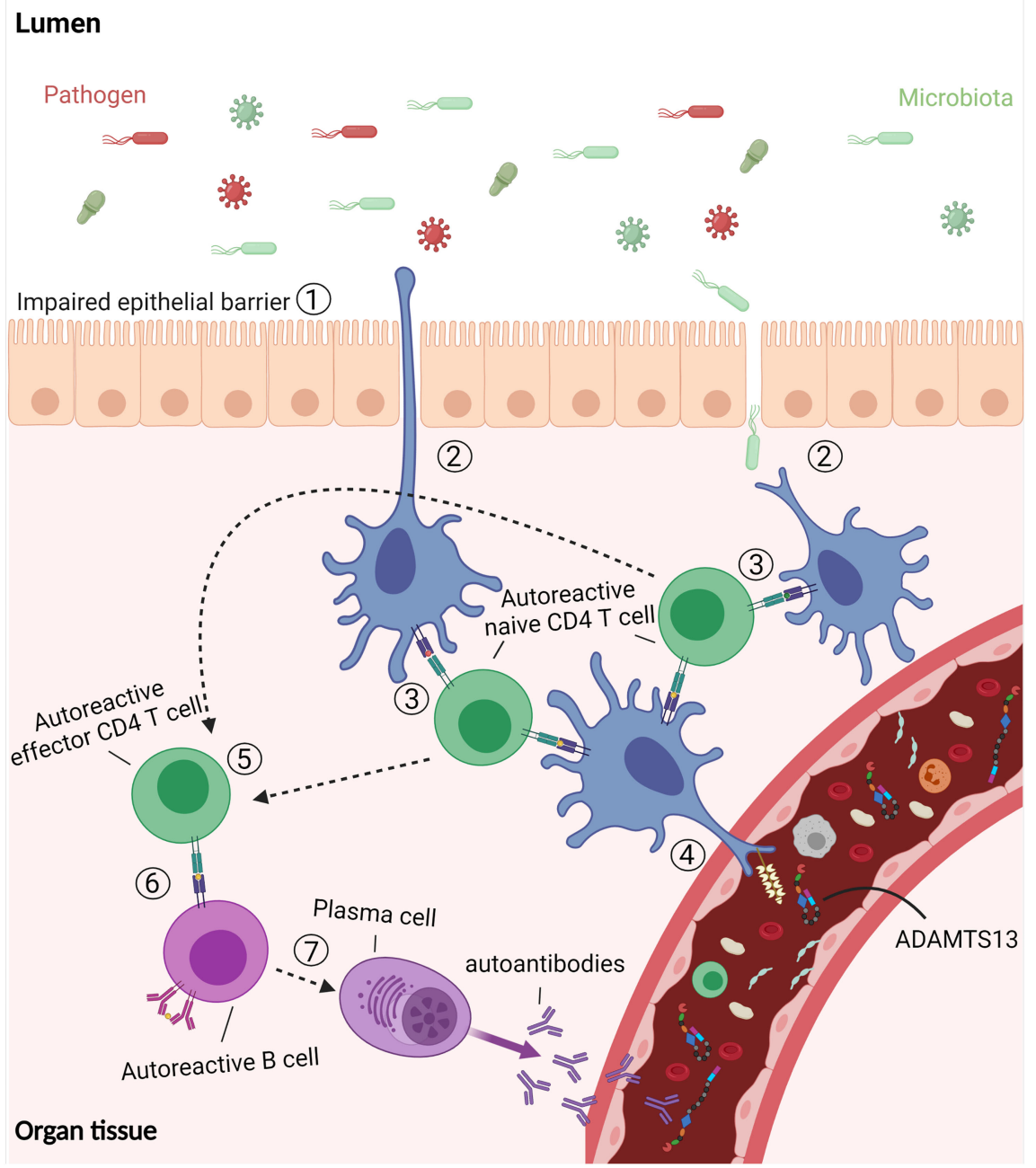

FIGURE 5 | The "breach" of tolerance in immune TTP. Infections disrupt the epithelial cell layer which results in the exposure of the immune system to microbiota as well as pathogens. The dendritic cells (DC) acquire antigens from the microorganisms by phagocytosis. Following processing, the DC activate cross-reactive naïve CD4 T cells which also recognize antigens derived from ADAMTS13. The activated CD4 T cells differentiate into effector CD4 T cells which interact with autoreactive $\mathrm{B}$ cells to induce differentiation of the B cells into autoantibodies-producing plasma cells. Figure created with Biorender.com. 
the induction of autoimmunity against ADAMTS13. Although the knowledge from other ADs gives insight to the possible immunopathogenesis of iTTP, several details of the processes leading to an immune response against ADAMTS13 remain to be uncovered. The findings in earlier studies seem very promising in pleading the case of molecular mimicry as a major underlying mechanism for the development of ADs and iTTP. Associations of HLA and iTTP have been identified, as they have been known for other ADs. ADAMTS13 peptides have been identified as T-cell epitopes in risk HLA alleles, and computational studies can be performed to find potential similar peptides from microorganisms, especially those commonly associated with iTTP at diagnosis. Some outcomes of such studies already exist. However, the search has to be continued and refined, both for infectious microorganisms and for microbiota, as done for other ADs (164). The use of bioinformatic tools in the homology search and the further validation using $\mathrm{T}$-cell reactivity assays could substantiate the model as proposed in this review. More insight into the TCRs of iTTP patients is also needed in this field, and an animal model that properly reproduces the immune features seen in humans would provide a substantial advancement in the case of iTTP autoimmunity mechanisms. Additionally, cross-reactive B-cell epitopes remain to be formally identified, and research here may be aided by means of 3D-structure comparison software's like CE-BLAST (165) or PDBeFold (166), by comparing available

\section{REFERENCES}

1. Kremer Hovinga JA, Coppo P, Lammle B, Moake JL, Miyata T, Vanhoorelbeke K. Thrombotic Thrombocytopenic Purpura. Nat Rev Dis Primers (2017) 3:17020. doi: 10.1038/nrdp.2017.20

2. Furlan M, Robles R, Solenthaler M, Wassmer M, Sandoz P, Lammle B. Deficient Activity of Von Willebrand Factor-Cleaving Protease in Chronic Relapsing Thrombotic Thrombocytopenic Purpura. Blood (1997) 89 (9):3097-103. doi: 10.1182/blood.V89.9.3097

3. Furlan M, Lammle B. Deficiency of Von Willebrand Factor-Cleaving Protease in Familial and Acquired Thrombotic Thrombocytopenic Purpura. Baillieres Clin Haematol (1998) 11(2):509-14. doi: 10.1016/S0950-3536(98)80064-4

4. Fujikawa K, Suzuki H, McMullen B, Chung D. Purification of Human Von Willebrand Factor-Cleaving Protease and its Identification as a New Member of the Metalloproteinase Family. Blood (2001) 98(6):1662-6. doi: 10.1182/blood.V98.6.1662

5. Soejima K, Mimura N, Hirashima M, Maeda H, Hamamoto T, Nakagaki T, et al. A Novel Human Metalloprotease Synthesized in the Liver and Secreted Into the Blood: Possibly, the Von Willebrand Factor-Cleaving Protease? J Biochem (2001) 130(4):475-80. doi: 10.1093/oxfordjournals.jbchem.a003009

6. Dong JF. Cleavage of Ultra-Large Von Willebrand Factor by ADAMTS-13 Under Flow Conditions. J Thromb Haemost (2005) 3(8):1710-6. doi: 10.1111/j.1538-7836.2005.01360.x

7. Xiang Y, de Groot R, Crawley JT, Lane DA. Mechanism of Von Willebrand Factor Scissile Bond Cleavage by a Disintegrin and Metalloproteinase With a Thrombospondin Type 1 Motif, Member 13 (ADAMTS13). Proc Natl Acad Sci USA (2011) 108(28):11602-7. doi: 10.1073/pnas.1018559108

8. Kremer Hovinga JA, Lammle B. Role of ADAMTS13 in the Pathogenesis, Diagnosis, and Treatment of Thrombotic Thrombocytopenic Purpura. Hematol Am Soc Hematol Educ Program (2012) 2012:610-6. doi: 10.1182/ asheducation.V2012.1.610.3798654

9. Verbij FC, Fijnheer R, Voorberg J, Sorvillo N. Acquired TTP: ADAMTS13 Meets the Immune System. Blood Rev (2014) 28(6):227-34. doi: 10.1016/j.blre.2014.07.004
ADAMTS13 crystal structures with those of proteins from microorganisms. Future studies will further uncover the missing pieces of the puzzle that is autoimmunity and loss of tolerance towards ADAMTS13.

\section{AUTHOR CONTRIBUTIONS}

AL, NG, and JV wrote the manuscript and prepared the figures. All authors contributed to the article and approved the submitted version.

\section{FUNDING}

Financial support was obtained from the Answering TTP foundation, Landsteiner Foundation for Blood Transfusion Research and The Netherlands Thrombosis Foundation. NG was supported by a grant from Sanquinnovate for the development of novel therapeutic compounds for treatment of iTTP. AL has been supported by a grant from the Answering TTP Foundation (grant year: 2018). NG has been supported by a grant from the European Union's Horizon 2020 research and innovation program under the Marie Sklodowska-Curie grant agreement number 675746 (PROFILE) and a grant from Sanquinnovate (SQI00060).

10. Thomas MR, de Groot R, Scully MA, Crawley JTB. Pathogenicity of AntiADAMTS13 Autoantibodies in Acquired Thrombotic Thrombocytopenic Purpura. Ebiomedicine (2015) 2(8):942-52. doi: 10.1016/j.ebiom.2015.06.007

11. Klaus C, Plaimauer B, Studt JD, Dorner F, Lammle B, Mannucci PM, et al. Epitope Mapping of ADAMTS13 Autoantibodies in Acquired Thrombotic Thrombocytopenic Purpura. Blood (2004) 103(12):4514-9. doi: 10.1182/ blood-2003-12-4165

12. Zheng XL, Wu HM, Shang D, Falls E, Skipwith CG, Cataland SR, et al. Multiple Domains of ADAMTS13 are Targeted by Autoantibodies Against ADAMTS13 in Patients With Acquired Idiopathic Thrombotic Thrombocytopenic Purpura. Haematologica (2010) 95(9):1555-62. doi: 10.3324/haematol.2009.019299

13. Scully M, Cataland S, Coppo P, de la Rubia J, Friedman KD, Kremer Hovinga J, et al. Consensus on the Standardization of Terminology in Thrombotic Thrombocytopenic Purpura and Related Thrombotic Microangiopathies. J Thromb Haemost (2017) 15(2):312-22. doi: 10.1111/jth.13571

14. Luken BM, Turenhout EA, Hulstein JJ, Van Mourik JA, Fijnheer R, Voorberg J. The Spacer Domain of ADAMTS13 Contains a Major Binding Site for Antibodies in Patients With Thrombotic Thrombocytopenic Purpura. Thromb Haemost (2005) 93(2):267-74. doi: 10.1160/TH04-05-0301

15. Pos W, Crawley JT, Fijnheer R, Voorberg J, Lane DA, Luken BM. An Autoantibody Epitope Comprising Residues R660, Y661, and Y665 in the ADAMTS13 Spacer Domain Identifies a Binding Site for the A2 Domain of VWF. Blood (2010) 115(8):1640-9. doi: 10.1182/blood-2009-06-229203

16. Pos W, Sorvillo N, Fijnheer R, Feys HB, Kaijen PH, Vidarsson G, et al Residues Arg568 and Phe592 Contribute to an Antigenic Surface for AntiADAMTS13 Antibodies in the Spacer Domain. Haematologica (2011) 96 (11):1670-7. doi: 10.3324/haematol.2010.036327

17. Wang A, Liu F, Dong N, Ma Z, Zhang J, Su J, et al. Thrombospondin-1 and ADAMTS13 Competitively Bind to VWF A2 and A3 Domains In Vitro. Thromb Res (2010) 126(4):e260-5. doi: 10.1016/j.thromres.2010.07.009

18. Jin SY, Skipwith CG, Zheng XL. Amino Acid Residues Arg(659), Arg(660), and $\operatorname{Tyr}(661)$ in the Spacer Domain of ADAMTS13 are Critical for Cleavage 
of Von Willebrand Factor. Blood (2010) 115(11):2300-10. doi: 10.1182/ blood-2009-07-235101

19. Scheiflinger F, Knobl P, Trattner B, Plaimauer B, Mohr G, Dockal M, et al. Nonneutralizing IgM and IgG Antibodies to Von Willebrand FactorCleaving Protease (ADAMTS-13) in a Patient With Thrombotic Thrombocytopenic Purpura. Blood (2003) 102(9):3241-3. doi: 10.1182/ blood-2003-05-1616

20. Pos W, Luken BM, Sorvillo N, Kremer Hovinga JA, Voorberg J. Humoral Immune Response to ADAMTS13 in Acquired Thrombotic Thrombocytopenic Purpura. J Thromb Haemost (2011) 9(7):1285-91. doi: 10.1111/j.15387836.2011.04307.x

21. Shenkman B, Einav Y. Thrombotic Thrombocytopenic Purpura and Other Thrombotic Microangiopathic Hemolytic Anemias: Diagnosis and Classification. Autoimmun Rev (2014) 13(4-5):584-6. doi: 10.1016/j.autrev. 2014.01.004

22. Norkin SA, Freedman HH, Evans GW. Thrombotic Thrombocytopenic Purpura in Siblings. Am J Med (1967) 43(2):294-303. doi: 10.1016/00029343(67)90172-6

23. Paz RA, Elijovich F, Barcat JA, Sanchez-Avalos JC. Fatal Simultaneous Thrombocytopenic Purpura in Siblings. Br Med J (1969) 4(5685):727-8. doi: 10.1136/bmj.4.5685.727

24. Wallace DC, Lovric A, Clubb JS, Carseldine DB. Thrombotic Thrombocytopenic Purpura in Four Siblings. Am J Med (1975) 58 (5):724-34. doi: 10.1016/0002-9343(75)90510-0

25. Hellman RM, Jackson DV, Buss DH. Thrombotic Thrombocytopenic Purpura and Hemolytic-Uremic Syndrome in HLA-Identical Siblings. Ann Intern Med (1980) 93(2):283-4. doi: 10.7326/0003-4819-93-2-283

26. Kirchner KA, Smith RM, Gockerman JP, Luke RG. Hereditary Thrombotic Thrombocytopenic Purpura: Microangiopathic Hemolytic Anemia, Thrombocytopenia, and Renal Insufficiency Occurring in Consecutive Generations. Nephron (1982) 30(1):28-30. doi: 10.1159/000182427

27. Elias M, Horowitz J, Tal I, Kohn D, Flatau E. Thrombotic Thrombocytopenic Purpura and Haemolytic Uraemic Syndrome in Three Siblings. Arch Dis Child (1988) 63(6):644-6. doi: 10.1136/adc.63.6.644

28. Joseph G, Smith KJ, Hadley TJ, Djulbegovic B, Troup GM, Oldfather J, et al. HLA-DR53 Protects Against Thrombotic Thrombocytopenic Purpura/ Adult Hemolytic Uremic Syndrome. Am J Hematol (1994) 47(3):189-93. doi: 10.1002/ajh.2830470308

29. Furlan M, Robles R, Galbusera M, Remuzzi G, Kyrle PA, Brenner B, et al. Von Willebrand Factor-Cleaving Protease in Thrombotic Thrombocytopenic Purpura and the Hemolytic-Uremic Syndrome. N Engl J Med (1998) 339 (22):1578-84. doi: 10.1056/NEJM199811263392202

30. Furlan M, Robles R, Solenthaler M, Lammle B. Acquired Deficiency of Von Willebrand Factor-Cleaving Protease in a Patient With Thrombotic Thrombocytopenic Purpura. Blood (1998) 91(8):2839-46. doi: 10.1182/ blood.V91.8.2839.2839_2839_2846

31. Tsai HM, Lian EC. Antibodies to Von Willebrand Factor-Cleaving Protease in Acute Thrombotic Thrombocytopenic Purpura. N Engl J Med (1998) 339 (22):1585-94. doi: 10.1056/NEJM199811263392203

32. Levy GG, Nichols WC, Lian EC, Foroud T, McClintick JN, McGee BM, et al. Mutations in a Member of the ADAMTS Gene Family Cause Thrombotic Thrombocytopenic Purpura. Nature (2001) 413(6855):488-94. doi: 10.1038/ 35097008

33. Scully M, Brown J, Patel R, McDonald V, Brown CJ, Machin S. Human Leukocyte Antigen Association in Idiopathic Thrombotic Thrombocytopenic Purpura: Evidence for an Immunogenetic Link. J Thromb Haemost (2010) 8 (2):257-62. doi: 10.1111/j.1538-7836.2009.03692.x

34. Coppo P, Busson M, Veyradier A, Wynckel A, Poullin P, Azoulay E, et al. HLA-DRB1*11: A Strong Risk Factor for Acquired Severe ADAMTS13 Deficiency-Related Idiopathic Thrombotic Thrombocytopenic Purpura in Caucasians. J Thromb Haemost (2010) 8(4):856-9. doi: 10.1111/j.1538-7836. 2010.03772.x

35. John ML, Hitzler W, Scharrer I. The Role of Human Leukocyte Antigens as Predisposing and/or Protective Factors in Patients With Idiopathic Thrombotic Thrombocytopenic Purpura. Ann Hematol (2012) 91(4):50710. doi: 10.1007/s00277-011-1384-z

36. Joly BS, Loiseau P, Darmon M, Leblanc T, Chambost H, Fouyssac F, et al. HLA-DRB $1^{*} 11$ is a Strong Risk Factor for Acquired Thrombotic
Thrombocytopenic Purpura in Children. Haematologica (2020) 105(10): e531. doi: 10.3324/haematol.2019.241968

37. Sinkovits G, Szilagyi A, Farkas P, Inotai D, Szilvasi A, Tordai A, et al. The Role of Human Leukocyte Antigen DRB1-DQB1 Haplotypes in the Susceptibility to Acquired Idiopathic Thrombotic Thrombocytopenic Purpura. Hum Immunol (2017) 78(2):80-7. doi: 10.1016/j.humimm. 2016.11.005

38. Sakai K, Kuwana M, Tanaka H, Hosomichi K, Hasegawa A, Uyama H, et al. HLA Loci Predisposing to Immune TTP in Japanese: Potential Role of the Shared ADAMTS13 Peptide Bound to Different HLA-Dr. Blood (2020) 135 (26):2413-9. doi: 10.1182/blood.2020005395

39. Arango MT, Perricone C, Kivity S, Cipriano E, Ceccarelli F, Valesini G, et al. HLA-DRB1 the Notorious Gene in the Mosaic of Autoimmunity. Immunol Res (2017) 65(1):82-98. doi: 10.1007/s12026-016-8817-7

40. Ye J, Gillespie KM, Rodriguez S. Unravelling the Roles of Susceptibility Loci for Autoimmune Diseases in the Post-GWAS Era. Genes (Basel) (2018) 9 (8):1-15. doi: 10.3390/genes9080377

41. Morgand M, Buffet M, Busson M, Loiseau P, Malot S, Amokrane K, et al. High Prevalence of Infectious Events in Thrombotic Thrombocytopenic Purpura and Genetic Relationship With Toll-Like Receptor 9 Polymorphisms: Experience of the French Thrombotic Microangiopathies Reference Center. Transfusion (2014) 54(2):389-97. doi: 10.1111/trf.12263

42. Farrugia M, Baron B. The Role of Toll-Like Receptors in Autoimmune Diseases Through Failure of the Self-Recognition Mechanism. Int J Inflam (2017) 2017:8391230. doi: 10.1155/2017/8391230

43. Chung SA, Criswell LA. PTPN22: Its Role in SLE and Autoimmunity. Autoimmunity (2007) 40(8):582-90. doi: 10.1080/08916930701510848

44. Mancini I, Giacomini E, Pontiggia S, Artoni A, Ferrari B, Pappalardo E, et al. The HLA Variant Rs6903608 Is Associated With Disease Onset and Relapse of Immune-Mediated Thrombotic Thrombocytopenic Purpura in Caucasians. J Clin Med (2020) 9(10):1-13. doi: 10.3390/jcm9103379

45. Stubbs MJ, Coppo P, Cheshire C, Veyradier A, Dufek S, Levine AP, et al. Identification of a Novel Genetic Locus Associated With Immune Mediated Thrombotic Thrombocytopenic Purpura. Haematologica (2021), 1-48. doi: 10.3324/haematol.2020.274639

46. Doyle HA, Mamula MJ. Post-Translational Protein Modifications in Antigen Recognition and Autoimmunity. Trends Immunol (2001) 22 (8):443-9. doi: 10.1016/S1471-4906(01)01976-7

47. Verbij FC, Stokhuijzen E, Kaijen PHP, van Alphen F, Meijer AB, Voorberg J. Identification of Glycans on Plasma-Derived ADAMTS13. Blood (2016) 128 (21):E51-E8. doi: 10.1182/blood-2016-06-720912

48. Purcell AW, van Driel IR, Gleeson PA. Impact of Glycans on T-Cell Tolerance to Glycosylated Self-Antigens. Immunol Cell Biol (2008) 86 (7):574-9. doi: 10.1038/icb.2008.48

49. Sorvillo N, Mizurini DM, Coxon C, Martinod K, Tilvawala R, Cherpokova D, et al. Plasma Peptidylarginine Deiminase IV Promotes VWF-Platelet String Formation and Accelerates Thrombosis After Vessel Injury. Circ Res (2019) 125(5):507-19. doi: 10.1161/CIRCRESAHA.118.314571

50. Valesini G, Gerardi MC, Iannuccelli C, Pacucci VA, Pendolino M, Shoenfeld Y. Citrullination and Autoimmunity. Autoimmun Rev (2015) 14(6):490-7. doi: 10.1016/j.autrev.2015.01.013

51. Becart S, Whittington KB, Prislovsky A, Rao NL, Rosloniec EF. The Role of Posttranslational Modifications in Generating Neo-Epitopes That Bind to Rheumatoid Arthritis-Associated HLA-DR Alleles and Promote Autoimmune T Cell Responses. PloS One (2021) 16(1):1-22. doi: 10.1371/ journal.pone.0245541

52. Yang $\mathrm{J}, \mathrm{Wu} \mathrm{Z}$, Long $\mathrm{Q}$, Huang $\mathrm{J}$, Hong $\mathrm{T}$, Liu $\mathrm{W}$, et al. Insights Into Immunothrombosis: The Interplay Among Neutrophil Extracellular Trap, Von Willebrand Factor, and ADAMTS13. Front Immunol (2020) 11:610696. doi: 10.3389/fimmu.2020.610696

53. Fuchs TA, Kremer Hovinga JA, Schatzberg D, Wagner DD, Lammle B. Circulating DNA and Myeloperoxidase Indicate Disease Activity in Patients With Thrombotic Microangiopathies. Blood (2012) 120(6):1157-64. doi: 10.1182/blood-2012-02-412197

54. Roose E, Schelpe AS, Joly BS, Peetermans M, Verhamme P, Voorberg J, et al. An Open Conformation of ADAMTS-13 is a Hallmark of Acute Acquired Thrombotic Thrombocytopenic Purpura. J Thromb Haemost (2018) 16 (2):378-88. doi: 10.1111/jth.13922 
55. Roose E, Schelpe AS, Tellier E, Sinkovits G, Joly BS, Dekimpe C, et al. Open ADAMTS13, Induced by Antibodies, is a Biomarker for Subclinical Immune-Mediated Thrombotic Thrombocytopenic Purpura. Blood (2020) 136(3):353-61. doi: 10.1182/blood.2019004221

56. Grillberger R, Casina VC, Turecek PL, Zheng XL, Rottensteiner H, Scheiflinger F. Anti-ADAMTS13 IgG Autoantibodies Present in Healthy Individuals Share Linear Epitopes With Those in Patients With Thrombotic Thrombocytopenic Purpura. Haematologica (2014) 99(4):e58-60. doi: 10.3324/haematol.2013.100685

57. Lombardi AM, Fabris R, Scarda A, Zanato V, Dal Pra C, Scarparo P, et al. Presence of Anti-ADAMTS13 Antibodies in Obesity. Eur J Clin Invest (2012) 42(11):1197-204. doi: 10.1111/j.1365-2362.2012.02710.x

58. Nowak AA, O'Brien HER, Henne P, Doerr A, Vanhoorelbeke K, Laffan MA, et al. ADAMTS-13 Glycans and Conformation-Dependent Activity. J Thromb Haemost (2017) 15(6):1155-66. doi: 10.1111/jth.13688

59. Holland CJ, Cole DK, Godkin A. Re-Directing CD4(+) T Cell Responses With the Flanking Residues of MHC Class II-Bound Peptides: The Core is Not Enough. Front Immunol (2013) 4:172. doi: 10.3389/fimmu.2013.00172

60. Panina-Bordignon P, Tan A, Termijtelen A, Demotz S, Corradin G, Lanzavecchia A. Universally Immunogenic T Cell Epitopes: Promiscuous Binding to Human MHC Class II and Promiscuous Recognition by T Cells. Eur J Immunol (1989) 19(12):2237-42. doi: 10.1002/eji.1830191209

61. Hammer J, Valsasnini P, Tolba K, Bolin D, Higelin J, Takacs B, et al. Promiscuous and Allele-Specific Anchors in HLA-DR-Binding Peptides. Cell (1993) 74(1):197-203. doi: 10.1016/0092-8674(93)90306-B

62. Cole DK, Bulek AM, Dolton G, Schauenberg AJ, Szomolay B, Rittase W, et al. Hotspot Autoimmune T Cell Receptor Binding Underlies Pathogen and Insulin Peptide Cross-Reactivity. J Clin Invest (2016) 126(9):3626. doi: $10.1172 /$ JCI85679

63. Sorvillo N, van Haren SD, Kaijen PH, ten Brinke A, Fijnheer R, Meijer AB, et al. Preferential HLA-DRB1*11-Dependent Presentation of CUB2-Derived Peptides by ADAMTS13-Pulsed Dendritic Cells. Blood (2013) 121 (17):3502-10. doi: 10.1182/blood-2012-09-456780

64. Hrdinova J, Verbij FC, Kaijen PHP, Hartholt RB, van Alphen F, Lardy N, et al. Mass Spectrometry-Assisted Identification of ADAMTS13-Derived Peptides Presented on HLA-DR and HLA-Dq. Haematologica (2018) 103 (6):1083-92. doi: 10.3324/haematol.2017.179119

65. Verbij FC, Turksma AW, de Heij F, Kaijen P, Lardy N, Fijnheer R, et al. CD4 $+\mathrm{T}$ Cells From Patients With Acquired Thrombotic Thrombocytopenic Purpura Recognize CUB2 Domain-Derived Peptides. Blood (2016) 127 (12):1606-9. doi: 10.1182/blood-2015-10-668053

66. Peyron I, Hartholt RB, Pedro-Cos L, van Alphen F, Brinke AT, Lardy N, et al. Comparative Profiling of HLA-DR and HLA-DQ Associated Factor VIII Peptides Presented by Monocyte-Derived Dendritic Cells. Haematologica (2018) 103(1):172-8. doi: 10.3324/haematol.2017.175083

67. Ferrari S, Mudde GC, Rieger M, Veyradier A, Kremer Hovinga JA, Scheiflinger F. IgG Subclass Distribution of Anti-ADAMTS13 Antibodies in Patients With Acquired Thrombotic Thrombocytopenic Purpura. J Thromb Haemost (2009) 7(10):1703-10. doi: 10.1111/j.1538-7836. 2009.03568.x

68. Bettoni G, Palla R, Valsecchi C, Consonni D, Lotta LA, Trisolini SM, et al. ADAMTS-13 Activity and Autoantibodies Classes and Subclasses as Prognostic Predictors in Acquired Thrombotic Thrombocytopenic Purpura. J Thromb Haemost (2012) 10(8):1556-65. doi: 10.1111/j.15387836.2012.04808.x

69. Schaller M, Vogel M, Kentouche K, Lammle B, Kremer Hovinga JA. The Splenic Autoimmune Response to ADAMTS13 in Thrombotic Thrombocytopenic Purpura Contains Recurrent Antigen-Binding CDR3 Motifs. Blood (2014) 124(23):3469-79. doi: 10.1182/blood-2014-04-561142

70. Burgdorf S, Kautz A, Bohnert V, Knolle PA, Kurts C. Distinct Pathways of Antigen Uptake and Intracellular Routing in CD4 and CD8 T Cell Activation. Science (2007) 316(5824):612-6. doi: 10.1126/science.1137971

71. Klein J, Sato A. The HLA System. First of Two Parts. N Engl J Med (2000) 343(10):702-9. doi: 10.1056/NEJM200009073431006

72. Ni K, O'Neill HC. The Role of Dendritic Cells in T Cell Activation. Immunol Cell Biol (1997) 75(3):223-30. doi: 10.1038/icb.1997.35

73. Kapsenberg ML. Dendritic-Cell Control of Pathogen-Driven T-Cell Polarization. Nat Rev Immunol (2003) 3(12):984-93. doi: 10.1038/nri1246
74. Kaiko GE, Horvat JC, Beagley KW, Hansbro PM. Immunological DecisionMaking: How Does the Immune System Decide to Mount a Helper T-Cell Response? Immunology (2008) 123(3):326-38. doi: 10.1111/j.13652567.2007.02719.x

75. Paul WE, Zhu J. How are $\mathrm{T}(\mathrm{H}) 2$-Type Immune Responses Initiated and Amplified? Nat Rev Immunol (2010) 10(4):225-35. doi: 10.1038/nri2735

76. Hemdan NY, Birkenmeier G, Wichmann G, Abu El-Saad AM, Krieger T, Conrad K, et al. Interleukin-17-Producing T Helper Cells in Autoimmunity. Autoimmun Rev (2010) 9(11):785-92. doi: 10.1016/j.autrev.2010.07.003

77. King C. New Insights Into the Differentiation and Function of T Follicular Helper Cells. Nat Rev Immunol (2009) 9(11):757-66. doi: 10.1038/nri2644

78. Schmetterer KG, Neunkirchner A, Pickl WF. Naturally Occurring Regulatory T Cells: Markers, Mechanisms, and Manipulation. FASEB J (2012) 26(6):2253-76. doi: 10.1096/fj.11-193672

79. Bouneaud C, Kourilsky P, Bousso P. Impact of Negative Selection on the T Cell Repertoire Reactive to a Self-Peptide: A Large Fraction of T Cell Clones Escapes Clonal Deletion. Immunity (2000) 13(6):829-40. doi: 10.1016/ S1074-7613(00)00080-7

80. Zehn D, Bevan MJ. T Cells With Low Avidity for a Tissue-Restricted Antigen Routinely Evade Central and Peripheral Tolerance and Cause Autoimmunity. Immunity (2006) 25(2):261-70. doi: 10.1016/j.immuni.2006.06.009

81. Lee HM, Bautista JL, Scott-Browne J, Mohan JF, Hsieh CS. A Broad Range of Self-Reactivity Drives Thymic Regulatory T Cell Selection to Limit Responses to Self. Immunity (2012) 37(3):475-86. doi: 10.1016/j.immuni.2012.07.009

82. Yin Y, Li Y, Mariuzza RA. Structural Basis for Self-Recognition by Autoimmune T-Cell Receptors. Immunol Rev (2012) 250(1):32-48. doi: 10.1111/imr.12002

83. Campillo-Davo D, Flumens D, Lion E. The Quest for the Best: How TCR Affinity, Avidity, and Functional Avidity Affect TCR-Engineered T-Cell Antitumor Responses. Cells (2020) 9(7):1-18. doi: 10.3390/cells9071720

84. Stone JD, Chervin AS, Kranz DM. T-Cell Receptor Binding Affinities and Kinetics: Impact on T-Cell Activity and Specificity. Immunology (2009) 126 (2):165-76. doi: 10.1111/j.1365-2567.2008.03015.x

85. Zhong S, Malecek K, Johnson LA, Yu Z, Vega-Saenz de Miera E, Darvishian F, et al. T-Cell Receptor Affinity and Avidity Defines Antitumor Response and Autoimmunity in T-Cell Immunotherapy. Proc Natl Acad Sci USA (2013) 110(17):6973-8. doi: 10.1073/pnas.1221609110

86. Sorvillo N, Pos W, van den Berg LM, Fijnheer R, Martinez-Pomares L, Geijtenbeek TB, et al. The Macrophage Mannose Receptor Promotes Uptake of ADAMTS13 by Dendritic Cells. Blood (2012) 119(16):3828-35. doi: 10.1182/blood-2011-09-377754

87. Verbij FC, Sorvillo N, Kaijen PHP, Hrdinova J, Peyron I, Fijnheer R, et al. The Class I Scavenger Receptor CD163 Promotes Internalization of ADAMTS13 by Macrophages. Blood Adv (2017) 1(5):293-305. doi: 10.1182/bloodadvances.2016001321

88. Reinhardt RL, Liang HE, Locksley RM. Cytokine-Secreting Follicular T Cells Shape the Antibody Repertoire. Nat Immunol (2009) 10(4):385-93. doi: 10.1038/ni.1715

89. Rojas M, Restrepo-Jimenez P, Monsalve DM, Pacheco Y, Acosta-Ampudia Y, Ramirez-Santana C, et al. Molecular Mimicry and Autoimmunity. J Autoimmun (2018) 95:100-23. doi: 10.1016/j.jaut.2018.10.012

90. Anaya JM. The Autoimmune Tautology. Arthritis Res Ther (2010) 12(6):147. doi: 10.1186/ar3175

91. Trost B, Lucchese G, Stufano A, Bickis M, Kusalik A, Kanduc D. No Human Protein is Exempt From Bacterial Motifs, Not Even One. Self Nonself (2010) 1(4):328-34. doi: 10.4161/self.1.4.13315

92. Kohm AP, Fuller KG, Miller SD. Mimicking the Way to Autoimmunity: An Evolving Theory of Sequence and Structural Homology. Trends Microbiol (2003) 11(3):101-5. doi: 10.1016/S0966-842X(03)00006-4

93. Ang CW, Jacobs BC, Laman JD. The Guillain-Barre Syndrome: A True Case of Molecular Mimicry. Trends Immunol (2004) 25(2):61-6. doi: 10.1016/ j.it.2003.12.004

94. Sui J, Hwang WC, Perez S, Wei G, Aird D, Chen LM, et al. Structural and Functional Bases for Broad-Spectrum Neutralization of Avian and Human Influenza A Viruses. Nat Struct Mol Biol (2009) 16(3):265-73. doi: 10.1038/ nsmb.1566

95. Luken BM, Kaijen PH, Turenhout EA, Kremer Hovinga JA, van Mourik JA, Fijnheer R, et al. Multiple B-Cell Clones Producing Antibodies Directed to 
the Spacer and Disintegrin/Thrombospondin Type-1 Repeat 1 (TSP1) of ADAMTS13 in a Patient With Acquired Thrombotic Thrombocytopenic Purpura. J Thromb Haemost (2006) 4(11):2355-64. doi: 10.1111/j.15387836.2006.02164.x

96. Pos W, Luken BM, Hovinga JAK, Turenhout EAM, Scheiflinger F, Dong JF, et al. VH1-69 Germline Encoded Antibodies Directed Towards ADAMTS13 in Patients With Acquired Thrombotic Thrombocytopenic Purpura. J Thromb Haemostasis (2009) 7(3):421-8. doi: 10.1111/j.1538-7836.2008.03250.x

97. Siegel D, Ostertag E. Inhibitory ADAMTS13 Monoclonal Autoantibodies Cloned From TTP Patients Show Restricted Gene Usage, Inhibit Murine ADAMTS13, and are Blocked by Rabbit Anti-Idiotypic Antibodies. Blood (2006) 108(11):31a-2a. doi: 10.1182/blood.V108.11.92.92

98. Gunther K, Garizio D, Nesara P. ADAMTS13 Activity and the Presence of Acquired Inhibitors in Human Immunodeficiency Virus-Related Thrombotic Thrombocytopenic Purpura. Transfusion (2007) 47(9):17106. doi: $10.1111 / j .1537-2995.2007 .01346 . \mathrm{x}$

99. Kosugi N, Tsurutani Y, Isonishi A, Hori Y, Matsumoto M, Fujimura Y. Influenza A Infection Triggers Thrombotic Thrombocytopenic Purpura by Producing the Anti-ADAMTS13 IgG Inhibitor. Intern Med (2010) 49 (7):689-93. doi: 10.2169/internalmedicine.49.2957

100. Law L, Ho G, Cen D, Stenger J. Atypical Manifestations of Coronavirus Disease 2019 (COVID-19)-Associated Autoimmune Thrombotic Thrombocytopenic Purpura. Clin Case Rep (2021) 9(3):1402-4. doi: $10.1002 / \mathrm{ccr} 3.3787$

101. Poddar N, Wang JC. Thrombotic Thrombocytopenic Purpura in a Patient With Interferon Treated Hepatitis C Successfully Treated With Rituximab. Hematol Rep (2013) 5(1):5-7. doi: 10.4081/hr.2013.e2

102. Booth KK, Terrell DR, Vesely SK, George JN. Systemic Infections Mimicking Thrombotic Thrombocytopenic Purpura. Am J Hematol (2011) 86(9):74351. doi: 10.1002/ajh.22091

103. Sahin O, Albayrak M, Yildiz A, Pala C, Aktas L, Maral S, et al. Refractory Thrombotic Thrombocytopenic Purpura in a Patient With Kaposi Sarcoma. Transfus Apher Sci (2019) 58(2):187-9. doi: 10.1016/j.transci.2019.02.003

104. De Leonardis F, Koronica R, Daniele RM, Santoro N. Thrombotic Thrombocytopenic Purpura in a Child Treated for Acute Lymphoblastic Leukemia: Case Report and Review of Literature. J Pediatr Hematol Oncol (2018) 40(7):558-9. doi: 10.1097/MPH.0000000000001050

105. Oka S, Nohgawa M. EB Virus Reactivation Triggers Thrombotic Thrombocytopenic Purpura in a Healthy Adult. Leuk Res Rep (2017) 8:1-3. doi: 10.1016/j.lrr.2017.06.001

106. Kawasaki Y, Toyoda H, Otsuki S, Iwasa T, Iwamoto S, Azuma E, et al. A Novel Wiskott-Aldrich Syndrome Protein Mutation in an Infant With Thrombotic Thrombocytopenic Purpura. Eur J Haematol (2013) 90 (2):164-8. doi: 10.1111/ejh.12057

107. Bastos MLA, Araujo RMO, Oliveira DS, Cavalcante ANM, Silva Junior GBD. Thrombotic Thrombocytopenic Purpura Associated With Dengue and Chikungunya Virus Coinfection: Case Report During an Epidemic Period. Rev Inst Med Trop Sao Paulo (2018) 60:e48. doi: 10.1590/s1678-9946201860048

108. Epelboin L, Bidaud B, Mosnier E, Le Turnier P, Vesin G, Walter G, et al. Fatal Case of Chikungunya and Concomitant Thrombotic Thrombocytopenic Purpura in French Guiana During Air Flight Medical Evacuation. J Travel Med (2017) 24(5):1-3. doi: 10.1093/jtm/tax028

109. Gringauz I, Carmel-Neiderman NN, Mangel T, Portnoy O, Segal G, Goren I. Marked Improvement in Refractory TTP Directly After H. pylori Eradication Ther Case Rep Hematol (2016) 2016:1568586. doi: 10.1155/2016/1568586

110. Talebi T, Fernandez-Castro G, Montero AJ, Stefanovic A, Lian E. A Case of Severe Thrombotic Thrombocytopenic Purpura With Concomitant Legionella Pneumonia: Review of Pathogenesis and Treatment. Am J Ther (2011) 18(5):e180-5. doi: 10.1097/MJT.0b013e3181d1b4a1

111. Caeiro Alves F, Aguiar R, Pessegueiro P, Pires C. Thrombotic Microangiopathy Associated With Mycoplasma Pneumoniae Infection. BMJ Case Rep (2018) 2018. doi: 10.1136/bcr-2017-222582

112. Cserti CM, Landaw S, Uhl L. Do Infections Provoke Exacerbations and Relapses of Thrombotic Thrombocytopenic Purpura? J Clin Apher (2007) 22 (1):21-5. doi: 10.1002/jca.20114

113. Illoh OC. Infection as a Cause of Early Relapse in Patients Recovering From Thrombotic Thrombocytopenic Purpura. J Clin Apher (2007) 22(4):204-9. doi: $10.1002 /$ jca.20119
114. Innes AJ, Matthey F. Red Cell Fragments can Mask Severe Thrombocytopenia. Blood (2017) 130(12):1484. doi: 10.1182/blood-2017-06-790477

115. Peetermans M, Meyers S, Liesenborghs L, Vanhoorelbeke K, De Meyer SF, Vandenbriele C, et al. Von Willebrand Factor and ADAMTS13 Impact on the Outcome of Staphylococcus Aureus Sepsis. J Thromb Haemost (2020) 18 (3):722-31. doi: 10.1111/jth.14686

116. Yagita M, Uemura M, Nakamura T, Kunitomi A, Matsumoto M, Fujimura Y. Development of ADAMTS13 Inhibitor in a Patient With Hepatitis C VirusRelated Liver Cirrhosis Causes Thrombotic Thrombocytopenic Purpura. J Hepatol (2005) 42(3):420-1. doi: 10.1016/j.jhep.2004.08.030

117. Kremer Hovinga JA, George JN. Hereditary Thrombotic Thrombocytopenic Purpura. N Engl J Med (2019) 381(17):1653-62. doi: 10.1056/NEJMra1813013

118. van Gorp EC, Suharti C, ten Cate H, Dolmans WM, van der Meer JW, ten Cate JW, et al. Review: Infectious Diseases and Coagulation Disorders. J Infect Dis (1999) 180(1):176-86. doi: 10.1086/314829

119. Goeijenbier M, van Wissen M, van de Weg C, Jong E, Gerdes VE, Meijers JC, et al. Review: Viral Infections and Mechanisms of Thrombosis and Bleeding. J Med Virol (2012) 84(10):1680-96. doi: 10.1002/jmv.23354

120. Alwan F, Vendramin C, Liesner R, Clark A, Lester W, Dutt T, et al. Characterization and Treatment of Congenital Thrombotic Thrombocytopenic Purpura. Blood (2019) 133(15):1644-51. doi: 10.1182/blood-2018-11-884700

121. van Dorland HA, Taleghani MM, Sakai K, Friedman KD, George JN, Hrachovinova I, et al. The International Hereditary Thrombotic Thrombocytopenic Purpura Registry: Key Findings at Enrollment Until 2017. Haematologica (2019) 104(10):2107-15. doi: 10.3324/haematol.2019.216796

122. Beristain-Covarrubias N, Perez-Toledo M, Thomas MR, Henderson IR, Watson SP, Cunningham AF. Understanding Infection-Induced Thrombosis: Lessons Learned From Animal Models. Front Immunol (2019) 10:2569. doi: 10.3389/fimmu.2019.02569

123. Bernardo A, Ball C, Nolasco L, Moake JF, Dong JF. Effects of Inflammatory Cytokines on the Release and Cleavage of the Endothelial Cell-Derived Ultralarge Von Willebrand Factor Multimers Under Flow. Blood (2004) 104 (1):100-6. doi: 10.1182/blood-2004-01-0107

124. Cao WJ, Niiya M, Zheng XW, Shang DZ, Zheng XL. Inflammatory Cytokines Inhibit ADAMTS13 Synthesis in Hepatic Stellate Cells and Endothelial Cells. J Thromb Haemost (2008) 6(7):1233-5. doi: 10.1111/ j.1538-7836.2008.02989.x

125. Favaloro EJ, Lippi G. Editorial Compilation Ix. Semin Thromb Hemost (2021) 47(01):6-10. doi: 10.1055/s-0040-1721751

126. Turecek PL, Peck RC, Rangarajan S, Reilly-Stitt C, Laffan MA, Kazmi R, et al. Recombinant ADAMTS13 Reduces Abnormally Up-Regulated Von Willebrand Factor in Plasma From Patients With Severe COVID-19. Thromb Res (2021) 201:100-12. doi: 10.1016/j.thromres.2021.02.012

127. Michaux C, Randrianasolo D, Vandenhende MA, Hessamfar M, Morlat P, Bonnet F. [Thrombotic Thrombocytopenic Purpura Associated With Interferon Therapy in a HIV and HCV Co-Infected Woman]. Rev Med Interne (2013) 34(12):773-5. doi: 10.1016/j.revmed.2013.03.003

128. Coppo P, Veyradier A. Current Management and Therapeutical Perspectives in Thrombotic Thrombocytopenic Purpura. Presse Med (2012) 41(3 Pt 2): e163-76. doi: 10.1016/j.lpm.2011.10.024

129. Dias PJ, Gopal S. Refractory Thrombotic Thrombocytopenic Purpura Following Influenza Vaccination. Anaesthesia (2009) 64(4):444-6. doi: 10.1111/j.1365-2044.2008.05823.x

130. Hermann R, Pfeil A, Busch M, Kettner C, Kretzschmar D, Hansch A, et al. [Very Severe Thrombotic Thrombocytopenic Purpura (TTP) After H1N1 Vaccination]. Med Klin (Munich) (2010) 105(9):663-8. doi: 10.1007/s00063010-1107-6

131. Kojima Y, Ohashi H, Nakamura T, Nakamura H, Yamamoto H, Miyata Y, et al. Acute Thrombotic Thrombocytopenic Purpura After Pneumococcal Vaccination. Blood Coagul Fibrinol (2014) 25(5):512-4. doi: 10.1097/ MBC.0000000000000058

132. Brodin-Sartorius A, Guebre-Egziabher F, Fouque D, Cozon G, Villar E, Laville $\mathrm{M}$, et al. Recurrent Idiopathic Thrombotic Thrombocytopenic Purpura: A Role for Vaccination in Disease Relapse? Am J Kidney Dis (2006) 48(3):e31-4. doi: 10.1053/j.ajkd.2006.04.090

133. Kadikoylu G, Yavasoglu I, Bolaman Z. Rabies Vaccine-Associated Thrombotic Thrombocytopenic Purpura. Transfus Med (2014) 24(6):4289. doi: $10.1111 /$ tme. 12160 
134. Sissa C, Al-Khaffaf A, Frattini F, Gaiardoni R, Mimiola E, Montorsi P, et al. Relapse of Thrombotic Thrombocytopenic Purpura After COVID-19 Vaccine. Transfus Apher Sci (2021) 103145:1. doi: 10.1016/j.transci.2021.103145

135. Karabulut K, Andronikashvili A, Kapici AH. Recurrence of Thrombotic Thrombocytopenic Purpura After mRNA-1273 COVID-19 Vaccine Administered Shortly After COVID-19. Case Rep Hematol (2021) 2021:4130138. doi: 10.1155/2021/4130138

136. Maayan H, Kirgner I, Gutwein O, Herzog-Tzarfati K, Rahimi-Levene N, Koren-Michowitz M, et al. Acquired Thrombotic Thrombocytopenic Purpura: A Rare Disease Associated With BNT162b2 Vaccine. J Thromb Haemost (2021) 19(9):2314-7. doi: 10.1111/jth.15420

137. Kirpalani A, Garabon J, Amos K, Patel S, Sharma AP, Ganesan SL, et al. Thrombotic Thrombocytopenic Purpura Temporally Associated With BNT162b2 Vaccination in an Adolescent Successfully Treated With Caplacizumab. Br J Haematol (2021), 1-3. doi: 10.1111/bjh.17782

138. Giuffrida G, Condorelli A, Di Giorgio MA, Markovic U, Sciortino R, Nicolosi $\mathrm{D}$, et al. Immune-Mediated Thrombotic Thrombocytopenic Purpura Following Pfizer-BioNTech COVID-19 Vaccine. Haematologica (2021), 1-8. doi: 10.3324/haematol.2021.279535

139. Yavasoglu I. Vaccination and Thrombotic Thrombocytopenic Purpura. Turk J Haematol (2020) 37(3):218-9. doi: 10.4274/tjh.galenos.2020.2020.0060

140. Henry BM, Benoit SW, de Oliveira MHS, Lippi G, Favaloro EJ, Benoit JL. ADAMTS13 Activity to Von Willebrand Factor Antigen Ratio Predicts Acute Kidney Injury in Patients With COVID-19: Evidence of SARS-CoV2 Induced Secondary Thrombotic Microangiopathy. Int J Lab Hematol (2021) 43 Suppl 1:129-36. doi: 10.1111/ijlh.13415

141. Lee HP, Selvaratnam V, Rajasuriar JS. Thrombotic Thrombocytopenic Purpura After ChAdOx1 Ncov-19 Vaccine. BMJ Case Rep (2021) 14(10). doi: 10.1136/bcr-2021-246049

142. Othman M, Baker AT, Gupalo E, Elsebaie A, Bliss CM, Rondina MT, et al. To Clot or Not to Clot? Ad is the Question-Insights on Mechanisms Related to Vaccine-Induced Thrombotic Thrombocytopenia. J Thromb Haemostasis (2021) 19:2845-56. doi: 10.31219/osf.io/d8ut5

143. Lundstrom K, Barh D, Uhal BD, Takayama K, Aljabali AAA, Abd El-Aziz TM, et al. COVID-19 Vaccines and Thrombosis-Roadblock or Dead-End Street? Biomolecules (2021) 11(7):1-11. doi: 10.3390/biom11071020

144. Segal Y, Shoenfeld Y. Vaccine-Induced Autoimmunity: The Role of Molecular Mimicry and Immune Crossreaction. Cell Mol Immunol (2018) 15(6):586-94. doi: 10.1038/cmi.2017.151

145. Kanduc D. From Influenza Infection to Anti-ADAMTS13 Autoantibodies via Cross-Reactivity. Infect Int (2019) 7(4):113-20. doi: 10.2478/ii-2019-0002

146. Gupta VK, Paul S, Dutta C. Geography, Ethnicity or Subsistence-Specific Variations in Human Microbiome Composition and Diversity. Front Microbiol (2017) 8:1162. doi: 10.3389/fmicb.2017.01162

147. Toivanen P, Vaahtovuo J, Eerola E. Influence of Major Histocompatibility Complex on Bacterial Composition of Fecal Flora. Infect Immun (2001) 69 (4):2372-7. doi: 10.1128/IAI.69.4.2372-2377.2001

148. Zheng D, Liwinski T, Elinav E. Interaction Between Microbiota and Immunity in Health and Disease. Cell Res (2020) 30(6):492-506. doi: 10.1038/s41422-020-0332-7

149. Russell JT, Roesch LFW, Ordberg M, Ilonen J, Atkinson MA, Schatz DA, et al. Genetic Risk for Autoimmunity is Associated With Distinct Changes in the Human Gut Microbiome. Nat Commun (2019) 10(1):3621. doi: 10.1038/ s41467-019-11460-x

150. Silverman M, Kua L, Tanca A, Pala M, Palomba A, Tanes C, et al. Protective Major Histocompatibility Complex Allele Prevents Type 1 Diabetes by Shaping the Intestinal Microbiota Early in Ontogeny. Proc Natl Acad Sci USA (2017) 114(36):9671-6. doi: 10.1073/pnas.1712280114

151. Paun A, Yau C, Danska JS. The Influence of the Microbiome on Type 1 Diabetes. J Immunol (2017) 198(2):590-5. doi: 10.4049/jimmunol.1601519

152. Porras AM, Shi Q, Zhou H, Callahan R, Montenegro-Bethancourt G, Solomons N, et al. Geographic Differences in Gut Microbiota Composition Impact Susceptibility to Enteric Infection. Cell Rep (2021) 36(4):109457. doi: 10.1016/j.celrep.2021.109457
153. Zhang X, Chen BD, Zhao LD, Li H. The Gut Microbiota: Emerging Evidence in Autoimmune Diseases. Trends Mol Med (2020) 26(9):862-73. doi: 10.1016/j.molmed.2020.04.001

154. Vanhoorelbeke K, De Meyer SF. Animal Models for Thrombotic Thrombocytopenic Purpura. J Thromb Haemost (2013) 11 Suppl 1:2-10. doi: $10.1111 /$ jth. 12255

155. Kim JW, Kwok SK, Choe JY, Park SH. Recent Advances in Our Understanding of the Link Between the Intestinal Microbiota and Systemic Lupus Erythematosus. Int J Mol Sci (2019) 20(19):1-13. doi: 10.3390/ijms20194871

156. Knight JC. Genomic Modulators of the Immune Response. Trends Genet (2013) 29(2):74-83. doi: 10.1016/j.tig.2012.10.006

157. Cavalli G, Hayashi M, Jin Y, Yorgov D, Santorico SA, Holcomb C, et al. MHC Class II Super-Enhancer Increases Surface Expression of HLA-DR and HLA-DQ and Affects Cytokine Production in Autoimmune Vitiligo. Proc Natl Acad Sci USA (2016) 113(5):1363-8. doi: 10.1073/pnas.1523482113

158. Gao P, Uzun Y, He B, Salamati SE, Coffey JKM, Tsalikian E, et al. Risk Variants Disrupting Enhancers of TH1 and TREG Cells in Type 1 Diabetes. Proc Natl Acad Sci USA (2019) 116(15):7581-90. doi: 10.1073/pnas. 1815336116

159. Eberl G. A New Vision of Immunity: Homeostasis of the Superorganism. Mucosal Immunol (2010) 3(5):450-60. doi: 10.1038/mi.2010.20

160. Liston A, Carr EJ, Linterman MA. Shaping Variation in the Human Immune System. Trends Immunol (2016) 37(10):637-46. doi: 10.1016/j.it.2016.08.002

161. Grignolio A, Mishto M, Faria AM, Garagnani P, Franceschi C, Tieri P. Towards a Liquid Self: How Time, Geography, and Life Experiences Reshape the Biological Identity. Front Immunol (2014) 5:153. doi: 10.3389/ fimmu.2014.00153

162. Moro-Garcia MA, Alonso-Arias R, Lopez-Larrea C. When Aging Reaches CD4+T-Cells: Phenotypic and Functional Changes. Front Immunol (2013) 4. doi: 10.3389/fimmu.2013.00107

163. Simon AK, Hollander GA, McMichael A. Evolution of the Immune System in Humans From Infancy to Old Age. Proc Biol Sci (2015) 282 (1821):20143085. doi: 10.1098/rspb.2014.3085

164. Venigalla SSK, Premakumar S, Janakiraman V. A Possible Role for Autoimmunity Through Molecular Mimicry in Alphavirus Mediated Arthritis. Sci Rep Uk (2020) 10(1):1-12. doi: 10.1038/s41598-019-55730-6

165. Qiu T, Yang Y, Qiu J, Huang Y, Xu T, Xiao H, et al. CE-BLAST Makes it Possible to Compute Antigenic Similarity for Newly Emerging Pathogens. Nat Commun (2018) 9(1):1772. doi: 10.1038/s41467-018-04171-2

166. Krissinel E, Henrick K. Secondary-Structure Matching (SSM), a New Tool for Fast Protein Structure Alignment in Three Dimensions. Acta Crystallogr D Biol Crystallogr (2004) 60(Pt 12 Pt 1):2256-68. doi: 10.1107/ S0907444904026460

Conflict of Interest: NG and JV are inventors on a patent-application describing novel compounds for the treatment of immune TTP.

The remaining authors declare that the research was conducted in the absence of any commercial or financial relationships that could be construed as a potential conflict of interest.

Publisher's Note: All claims expressed in this article are solely those of the authors and do not necessarily represent those of their affiliated organizations, or those of the publisher, the editors and the reviewers. Any product that may be evaluated in this article, or claim that may be made by its manufacturer, is not guaranteed or endorsed by the publisher.

Copyright (c) 2021 Laghmouchi, Graca and Voorberg. This is an open-access article distributed under the terms of the Creative Commons Attribution License (CC BY). The use, distribution or reproduction in other forums is permitted, provided the original author(s) and the copyright owner(s) are credited and that the original publication in this journal is cited, in accordance with accepted academic practice. No use, distribution or reproduction is permitted which does not comply with these terms. 